\title{
Neutralizing S1P inhibits intratumoral hypoxia, induces vascular remodelling and sensitizes to chemotherapy in prostate cancer
}

\author{
Isabelle Ader ${ }^{1,2,3}$, Cécile Gstalder ${ }^{1,2,3, *}$, Pierre Bouquerel ${ }^{1,2,3, *}$, Muriel Golzio ${ }^{1,2}$, \\ Guillaume Andrieu ${ }^{1,2,3}$, Santiago Zalvidea ${ }^{5}$, Sylvain Richard ${ }^{5}$, Roger A. Sabbadini ${ }^{6}$, \\ Bernard Malavaud ${ }^{1,2,3,4}$, Olivier Cuvillier ${ }^{1,2,3}$ \\ ${ }^{1}$ CNRS, Institut de Pharmacologie et de Biologie Structurale, Toulouse, France \\ ${ }^{2}$ Université de Toulouse, UPS, IPBS, Toulouse, France \\ ${ }^{3}$ Equipe Labellisée Ligue Contre le Cancer, Toulouse, France \\ ${ }^{4}$ Hôpital Rangueil, Service d’Urologie et de Transplantation Rénale, Toulouse, France \\ ${ }^{5}$ INSERM U1046, Université Montpellier 1, Université Montpellier 2, CHU Arnaud de Villeneuve, Montpellier, France \\ ${ }^{6}$ Lpath Inc., San Diego, CA, USA \\ *These authors have contributed equally to this work \\ Correspondence to: \\ Olivier Cuvillier, e-mail: olivier.cuvillier@ipbs.fr, olivier.cuvillier@inserm.fr \\ Keywords: angiogenesis, hypoxia, sphingolipid, vessel normalization \\ Received: December 01, $2014 \quad$ Accepted: January 12, 2015 \\ Published: January 29, 2015
}

\section{ABSTRACT}

Hypoxia promotes neovascularization, increased tumor growth, and therapeutic resistance. The transcription factor, hypoxia-inducible factor 1a (HIF-1a), has been reported as the master driver of adaptation to hypoxia. We previously identified the sphingosine kinase 1/sphingosine 1-phosphate (SphK1/S1P) pathway as a new modulator of HIF-1a under hypoxia. Taking advantage of a monoclonal antibody neutralizing extracellular S1P (sphingomab), we report that inhibition of S1P extracellular signaling blocks HIF-1a accumulation and activity in several cancer cell models exposed to hypoxia. In an orthotopic xenograft model of prostate cancer, we show that sphingomab reduces hypoxia and modifies vessel architecture within 5 days of treatment, leading to increased intratumoral blood perfusion. Supporting the notion that a transient vascular normalization of tumor vessels is the mechanism by which sphingomab exerts its effects, we demonstrate that administration of the antibody for 5 days before chemotherapy is more effective at local tumor control and metastatic dissemination than any other treatment scheduling. These findings validate sphingomab as a potential new normalization agent that could contribute to successful sensitization of hypoxic tumors to chemotherapy.

\section{INTRODUCTION}

Sphingosine 1-phosphate (S1P) is a bioactive sphingolipid metabolite regulating pleiotropic activities such as proliferation, survival, migration, inflammation or angiogenesis [1-4]. The S1P content in cells is low and is kept under control through a delicately regulated balance between its synthesis and its degradation. The balance between the intracellular levels of S1P and its metabolic precursors, ceramide and sphingosine, has been suggested to be a switch determining whether a cell proliferates or dies [5]. The predominant regulator of this ceramide/S1P balance is the sphingosine kinase-1 (SphK1) isoform, which produces S1P from sphingosine [6]. Once generated, S1P is exported by specific transporters such as spinster 2 (Spns2) [7-9], to exert paracrine or autocrine effects as a ligand for five high-affinity $\mathrm{G}$ protein-coupled receptors $\left(\mathrm{S}_{1} \mathrm{P}_{1-5}\right)$, with specific effects dictated by the predominance of S1P receptor subtypes expressed [10]. Alternative GPCR-independent signaling of S1P also exist [11] with recent findings demonstrating direct modulation of several intracellular proteins $[12,13]$.

In cancer, S1P metabolism is often found to be dysregulated directing attention to the SphK1/ S1P signaling pathway as a target for anti-cancer drug discovery [14-16]. In a number of solid tumors, high 
SphK1 expression correlates with a significant decrease in survival rate in patients [17-20]. The S1P produced by SphK1 is widely appreciated as a general growthlike factor and a potent protector against apoptosis induced by cytotoxic agents and other therapies in various cancer cell and animal models [14]. S1P is also thought to be as pro-angiogenic as basic fibroblast growth factor and Vascular Endothelial Growth Factor (VEGF) in promoting the development of vascular networks in vivo [21-24]. A number of preclinical studies have shown that pharmacological inhibition of SphK1 could be efficacious in decreasing tumor size or sensitize to chemo- or radiotherapy [25-28]. Interestingly, the anticancer activity of an anti-S1P monoclonal antibody (sphingomab $^{\mathrm{TM}}$ ) [29], which neutralizes S1P and inhibits its extracellular signaling, provides evidence of the importance of exogenous S1P in mediating tumor growth and metastatic potential $[23,30,31]$.

Hypoxia is a reduction in the normal level of tissue oxygen tension and occurs in many pathological conditions including cancer [32] where it contributes to the development of an aggressive phenotype and a poor prognostic in patients [33]. As a tumor develops, the diffusion distance from the existing vasculature increases resulting in hypoxia, which in turn drives the overexpression of angiogenic factors such as VEGF, leading to the formation of a new vasculature in an attempt to provide adequate supply of oxygen and nutriments [34, 35]. Somewhat paradoxically, such unleashed angiogenesis generates a highly disorganized and immature vascular network with impaired transport characteristics resulting in spatial and temporal inadequacies in delivery of oxygen, thereby exacerbating tumor hypoxia and fuelling a self-reinforcing vicious cycle [36, 37]. As a result of the leakiness of tumor vessels, impaired blood flow and interstitial hypertension interfere with the delivery of therapeutics reducing their efficacy while promoting the escape of cancer cells [37-41]. At the cellular level, the activation of the transcription factor hypoxia-inducible factor 1 (HIF-1) [42], has been identified as a master regulator of the response of cancer cells to hypoxia, triggering the expression of multiple target genes contributing to angiogenesis, treatment failure, invasion/ metastasis, altered metabolism and genomic instability $[32,43]$.

Given its central role in tumor progression and resistance to therapy, targeting hypoxia-induced angiogenesis represent an attractive strategy in cancer centered on two molecular targets, HIF-1 and VEGF [44-46]. As the direct inhibition of a transcription factor is a challenging task [47], targeting upstream signaling pathways leading to HIF-1 activation or downstream effectors regulated by HIF-1 such as VEGF may represent a more practical strategy and a wide range of pharmacological approaches have been proposed including the targeting of the SphK1/S1P signaling [48, 49]. Indeed, we previously identified SphK1/S1P signaling as a new canonical modulator of HIF-1 activity under hypoxic conditions owing to a decreased proteasome degradation of HIF- $1 \alpha$ subunit mediated by the Akt/GSK3 $\beta$ pathway in various cancer cell models [50]. Because Akt signaling can be activated by Gi-coupling of all subtypes of S1P receptors [10] and because $\mathrm{S} 1 \mathrm{P}$ has been shown to be released from hypoxic cells $[51,52]$, we have explored the effects of the neutralization of extracellular S1P with antiS1P monoclonal antibody sphingomab, currently under clinical development [15]. The goal of this study was to demonstrate preclinical proof of concept in mice bearing orthotopic prostate tumors that sphingomab could reduce intratumoral hypoxia and associated vascular network malfunction by enhancing blood perfusion to significantly improve delivery and efficacy of docetaxel, the standard chemotherapy for prostate cancer.

\section{RESULTS}

\section{Extracellular S1P regulates HIF-1 $\alpha$ level under hypoxia in several cancer cell lineages}

We previously identified SphK1 as a modulator of HIF- $1 \alpha$ as a key mediator of the adaptive response to hypoxia in multiple cancer cell models [50]. These studies led us to propose a strategy for controlling tumor hypoxia and its biological consequences [48]. To substantiate that inhibition of the SphK1/S1P pathway could represent a pertinent idea, we evaluated the relevance of inhibiting the extracellular S1P signaling with regard to HIF-1 $\alpha$ accumulation under hypoxia in cancer cells. We took advantage of a monoclonal antibody (mAb), sphingomab, that binds to and neutralizes extracellular S1P [23, 29]. As shown in Figure 1A, sphingomab inhibited accumulation of HIF- $1 \alpha$ in a concentration-dependent manner in human PC-3 prostate cancer cells. The ability of the anti-S1P $\mathrm{mAb}$ to inhibit HIF-1 $\alpha$ accumulation was tested in two other models, including the lung adenocarcinoma cell line A549, and the glioblastoma cell line U87. A similar dosedependent action of the anti-S1P mAb on HIF-1 $\alpha$ content was observed in these models (Figure 1A). S1P is mainly produced intracellularly by SphK1 and exerts its paracrine/ autocrine effects by being secreted into the tumor microenvironment. Spinster 2 (Spns2) has been recently suggested to be the primary transporter in the release of S1P [7-9, 53, 54]. When PC-3, A549 and U87 cells were treated with Spns2-specific siRNAs, the expression of Spns2 protein decreased to less than $10-20 \%$ of the control with two different siRNAs tested (siSpns2a and siSpns2b) (Figure 1B). The transient knockdown of Spns2 using these two different siRNAs was associated with a significant inhibitory effect on HIF- $1 \alpha$ accumulation under hypoxia (Figure 1C). Importantly, the decrease of HIF-1 $\alpha$ protein content by Spns 2 targeting was markedly reversed when cells were exposed to S1P (Figure 1D). These results 
A.

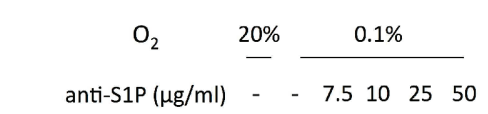

PC-3

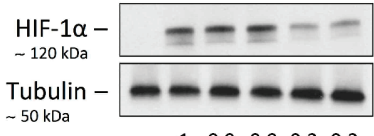

$\begin{array}{llllllllll}1 & 0.9 & 0.9 & 0.3 & 0.3\end{array}$
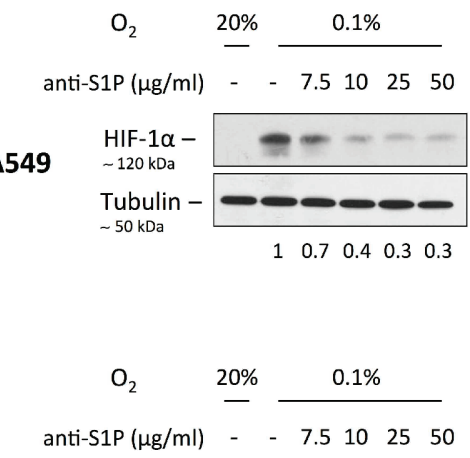

U87

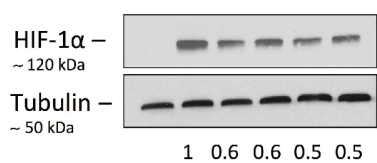

B.
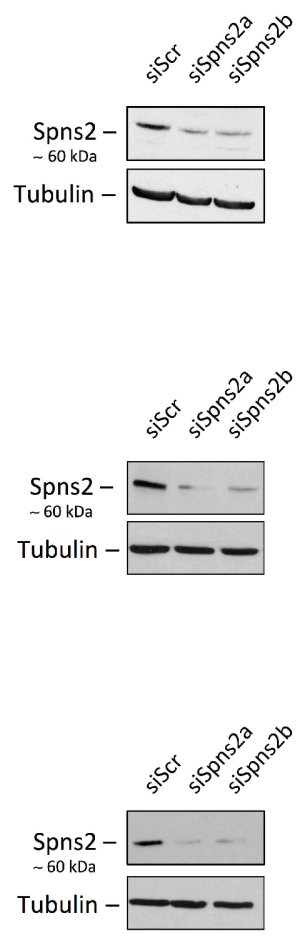

C.
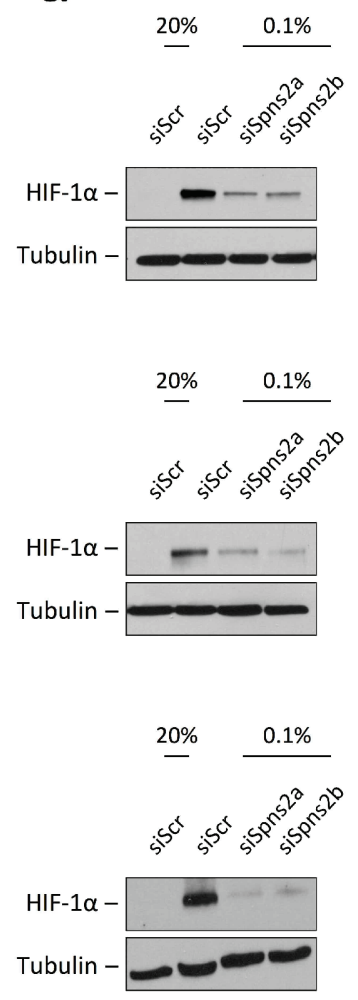

D.
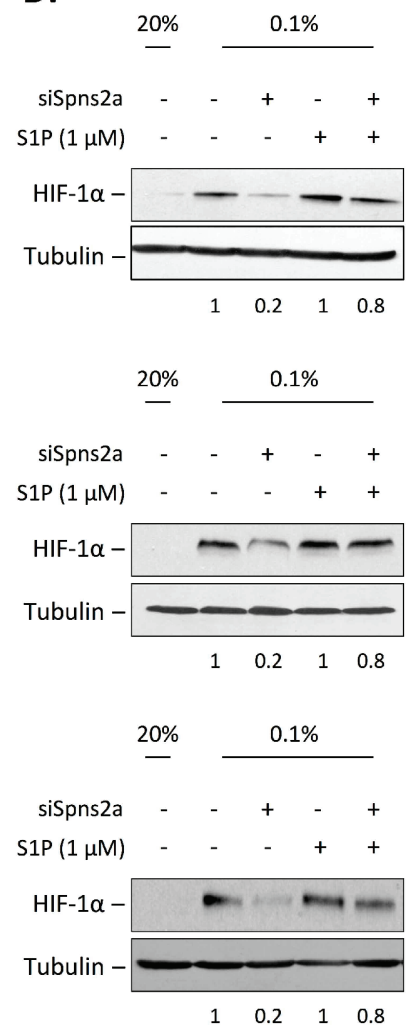

Figure 1: Extracellular S1P regulates HIF-1 $\alpha$ level under hypoxia. (A) Human PC-3, A549 and U87 cells were treated with the indicated concentrations of anti-S1P mAb (anti-S1P) for $2 \mathrm{~h}$, then incubated under normoxia $\left(20 \% \mathrm{O}_{2}\right)$ or hypoxia $\left(0.1 \% \mathrm{O}_{2}\right)$ for an additional 6 h. HIF-1 $\alpha$ expression was analyzed by immunoblotting using an anti-HIF-1 $\alpha$ antibody. (B) PC-3, A549 and U87 cells were untransfected or transfected with $90 \mathrm{nmol} / \mathrm{L}$ of two different siSpns2 (siSpns2a and siSpns2b) or scrambled siRNA (siScr) for $72 \mathrm{~h}$. Cell lysates were assayed for Spns2 expression by Western blot. (C) PC-3, A549 and U87 cells were untransfected or transfected with 90 $\mathrm{nmol} / \mathrm{L}$ of two different siSpns2 (siSpns2a) and siSpns2b) or scrambled siRNA (siScr) for $72 \mathrm{~h}$, then incubated under normoxia or hypoxia for an additional $6 \mathrm{~h}$. Cell lysates were assayed for HIF-1 $\alpha$ expression by Western blot. (D) PC-3, A549 and U87 cells were untransfected or transfected with $90 \mathrm{nmol} / \mathrm{L}$ of siSpns2a for $72 \mathrm{~h}$. The cells were then washed and left in DMEM without serum for $12 \mathrm{~h}$ before the incubation under normoxia or hypoxia without or with $1 \mu \mathrm{M} \mathrm{S1P}$ for an additional $6 \mathrm{~h}$. Cells were lysed and HIF-1 $\alpha$ expression was analyzed by immunoblotting with an anti-HIF-1 $\alpha$ antibody. For all experiments, similar results were obtained in at least three independent experiments, and equal loading was monitored using antibody to $\alpha$-tubulin.

agree with the data in Figure 1A and demonstrate that extracellular S1P released from cancer cells is critical to regulate HIF- $1 \alpha$ accumulation under hypoxia, regardless of the experimental conditions (10\% FBS in Figure 1A versus serum free conditions in Figure 1D).

\section{Neutralization of extracellular S1P downregulates HIF-1 $\alpha$ expression and activity in vivo}

To extend our in vitro findings, and because the anti-S1P mAb we used is under clinical development, the antibody's ability to inhibit HIF-1 $\alpha$ accumulation and transcriptional activity in vivo was tested in an orthotopic model of prostate cancer using the PC-3 cell line, because hypoxic response is largely dependent on the vascular microenvironment and very poorly replicated in subcutaneous models [55]. As previously reported $[25,56]$,
21 days after implantation of human GFP-overexpressing $\mathrm{PC}-3$ in nude mice, the histology of the tumor was consistent with poorly differentiated prostate cancer (data not shown) and animals were treated every other day for up to 9 days with $50 \mathrm{mg} / \mathrm{kg}$ sphingomab or the isotypematched IgG control by i.p. administration. Blood and primary tumors were collected from animals sacrificed at Day 0 or after 3, 5, 7 and 9 days of treatment with anti-S1P or IgG control antibodies. The excised tumors were first evaluated for immunohistochemical analysis of HIF- $1 \alpha$ expression. As shown in Figure 2A, anti-HIF-1 $\alpha$-labeled sections showed a marked decrease in staining of tumor cells in mice treated for 5 days with the anti-S1P mAb. A highly significant reduction of the number of HIF-1 $\alpha$ positive cells in tumor sections was observed from 5 to 7 days of treatment $(P<0.0001)$ but returned to the control value at 9 days suggesting a transient effect of the anti$\mathrm{S} 1 \mathrm{P} \mathrm{mAb}$ (Figure 2B). Western blot analysis on tumor 
B.

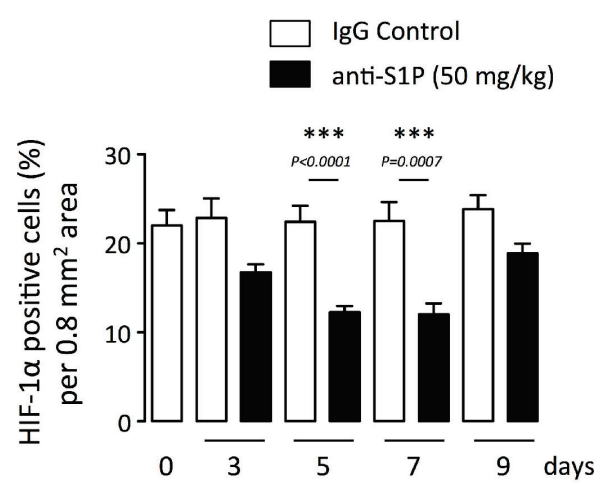

C.

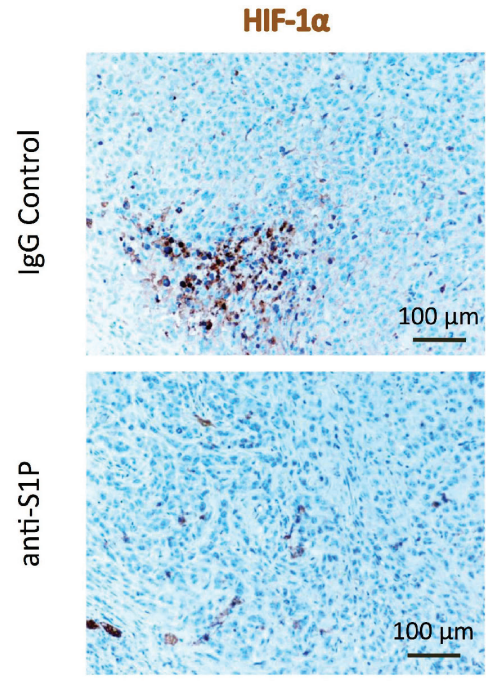

D.

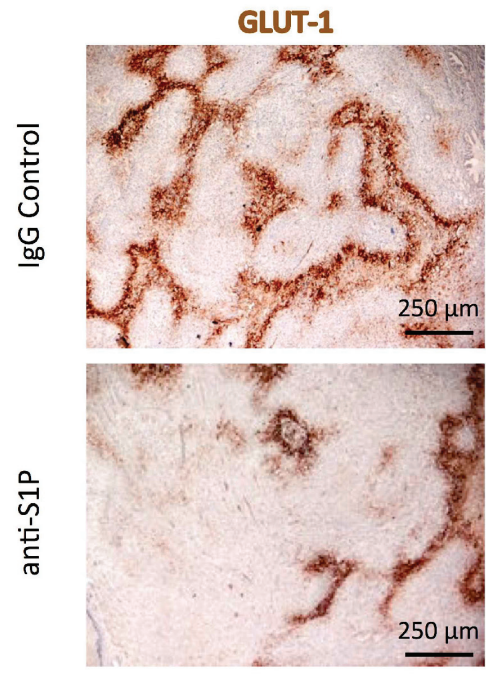

A.

E.

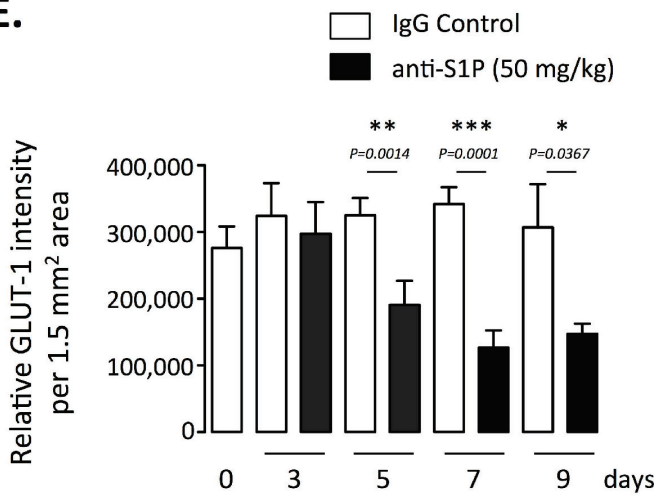

F.

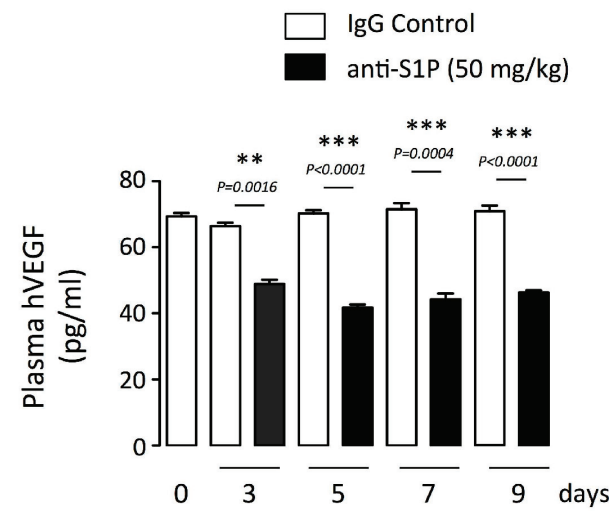

Figure 2: Effect of S1P neutralization on HIF-1 $\alpha$ expression and activity in vivo. Nude mice were injected in prostate with PC-3/GFP cells to form orthotopic xenografts. 21 days after injection, mice were treated every odd day with $50 \mathrm{mg} / \mathrm{kg}$ anti-S1P mAb or IgG control. After 3, 5, 7 and 9 days of treatment, mice were sacrificed and the primary tumors and blood were collected. (A) HIF-1 $\alpha$ staining of representative regions of tumor sections from animals treated for 5 days with $50 \mathrm{mg} / \mathrm{kg}$ anti-S1P antibody or IgG control. Scale bar, $100 \mu \mathrm{M}$. (B) Graph represents percentage of HIF-1 $\alpha$ positive cells per $0.8 \mathrm{~mm} 2$ area after 3, 5, 7 and 9 days of treatment. Columns, mean of four mice per group; bars, SEM. (C) Analysis of HIF-1 $\alpha$ protein expression by Western blotting in tumor lysates harvested from three mice per group after 5 days of treatment with IgG control (lane 1-3) or anti-S1P (lane 4-6). $\alpha$-tubulin was used as loading control. (D) GLUT-1 staining of representative regions of tumor sections from animals treated for 5 days with $50 \mathrm{mg} / \mathrm{kg}$ anti-S1P mAb or IgG control. Scale bar, $250 \mu \mathrm{M}$. (E) Graph represents relative GLUT-1 intensity per $1.5 \mathrm{~mm}^{2}$ area after 3, 5,7 and 9 days of treatment. Columns, mean of four mice per group; bars, SEM. (F) Plasma hVEGF concentrations in tumor-bearing mice after 3, 5, 7 and 9 days of treatment with $50 \mathrm{mg} / \mathrm{kg}$ anti-S1P antibody or IgG control. Columns, mean of four mice per group; bars, SEM. 
lysates collected at Day 5 confirmed the marked decrease of HIF- $1 \alpha$ protein expression when animals were treated with anti-S1P mAb in all samples examined (Figure 2C).

GLUT-1-stained sections revealed that inhibitory effect of the anti-S1P mAb was not restricted to HIF$1 \alpha$ protein accumulation but was also correlated with an inhibition of its transcriptional activity (Figure 2D). The treatment with anti-S1P mAb led to more than 50\% inhibition of GLUT-1 expression as early as 5 days of treatment up to 9 days with a maximal effect seen at Day 7 (Figure 2E). In addition, animals treated with the anti-S1P mAb had significantly reduced levels of circulating proangiogenic human VEGF (hVEGF) produced by the PC-3 xenografts (Figure 2F). Collectively these in vivo data demonstrate that S1P neutralization not only downregulates HIF- $1 \alpha$ content but also decreases the expression of GLUT-1 and the secretion of VEGF, two main factors depending on HIF- $1 \alpha$ transcriptional activity.

\section{Neutralization of S1P is associated with decreased intratumoral hypoxia, vascular remodelling and increased blood flow}

We previously observed that neutralization of S1P was associated with a reduction in the release of the potent vascular permeability factor VEGF from tumors, validating the sphingomab as an antiangiogenic agent [23]. We therefore analyzed effects of the antibody on the vasculature of orthotopic PC-3 tumor using immunohistochemical expression of CD34 as biological marker of angiogenesis. In agreement with the in vivo effect formerly reported in a subcutaneous A549 model [23], immunohistochemical analysis indicated a marked decrease in microvessel density in mice treated with the anti-S1P mAb throughout all the experiment time course (Figure 3A and 3B). The remaining vessels seemed to be opened indicating that "immature" vessels were likely preferentially eliminated (Figure 3A). The treatment with the anti-S1P mAb was accompanied by a marked reduction of intratumoral hypoxia as measured by pimonidazole staining, an effect that was significant as early as 5 days of treatment with a persisting effect that peaked at Day 7 (Figure 3C and 3D).

We next determined how hypoxia and neoangiogenesis were antagonized by the anti-S1P mAb. We first evaluated the architecture and the functional status of tumor vasculature. Because perivascular pericytes play a critical role in vessel maturation and stabilization [37], a double staining for pericytes (a-smooth muscle actin or $\alpha$-SMA) and endothelial cells (CD34) was performed to quantify the extent of pericyte coverage. A significant increase of the number of $\alpha$-SMA-positive intratumoral blood vessels was found in tumor-bearing animals treated with anti-S1P mAb, demonstrating the characteristic development of more mature vessels (Figure 4A and 4B).
As noticed for VEGF level and intratumoral hypoxia markers, the effect of sphingomab was evident after 5 days of treatment and maintained overtime (up to 9 days). To examine whether the morphological vessel normalization obtained by neutralizing S1P could translate into a functional vasculature, blood perfusion was assessed by a non-invasive real-time imaging using high frequency ultrasound to allow for longitudinal study on the same animal $[57,58]$. At different times after administration of anti-S1P mAb or control IgG, the slope and magnitude of microbubble contrast agent influx was measured to quantify the blood flow in vessels (Figure 4C and 4D). In anti-S1P mAb-treated mice, tumor perfusion significantly augmented as early as 5 days of administration, peaked at Day 7 (over 3-fold increase), then returned to basal level by Day 13 (Figure 4C and 4D). Collectively, these results showing the reduction in tumor hypoxia and enhanced vascular flow when S1P is neutralized support the notion that a transient "vascular normalization" [41] is the mechanism by which anti-S1P mAb exerts its effects, an effect which could enhance the efficacy of cytotoxic agents (see below).

\section{Anti-S1P mAb's direct effects on tumor cell proliferation and apoptosis}

S1P is a well-established proliferative and antiapoptotic mediator [5,59], the ability of anti-S1P antibody to alter cell proliferation and death of PC-3 xenograft was also evaluated. The Ki67 proliferation marker was used to estimate the fraction of viable cells undergoing active proliferation within the tumor. Anti-S1P mAb-treated tumors exhibited a notable decrease in cell proliferation rate that was evident after 5 days of administration (Figure 5A and 5B). Tumor cell death was assessed by the activation of the apoptotic executioner caspase-3. In agreement with previous reports showing that S1P inhibits activation of caspase-3 [23, 60], the treatment with anti-S1P mAb was associated with increased apoptosis as reflected by the increased level of cleaved caspase- 3 (Figure 5C and 5D). These data suggest that the proliferative and protective antiapoptotic effects of S1P are mitigated when extracellular S1P is neutralized by the anti-S1P antibody.

\section{Anti-S1P mAb-induced vascular normalization sensitizes to chemotherapy in established orthotopic PC-3/GFP tumors in mice}

Hypoxia plays a central role in tumor resistance to therapy including chemotherapy [45] and preclinical and clinical data support and offer a rationale of why a therapy aimed at increasing blood flow should result in improved drug delivery $[39,40]$. We hypothesized that the vascular normalization period we observed with the anti-S1P 
A.
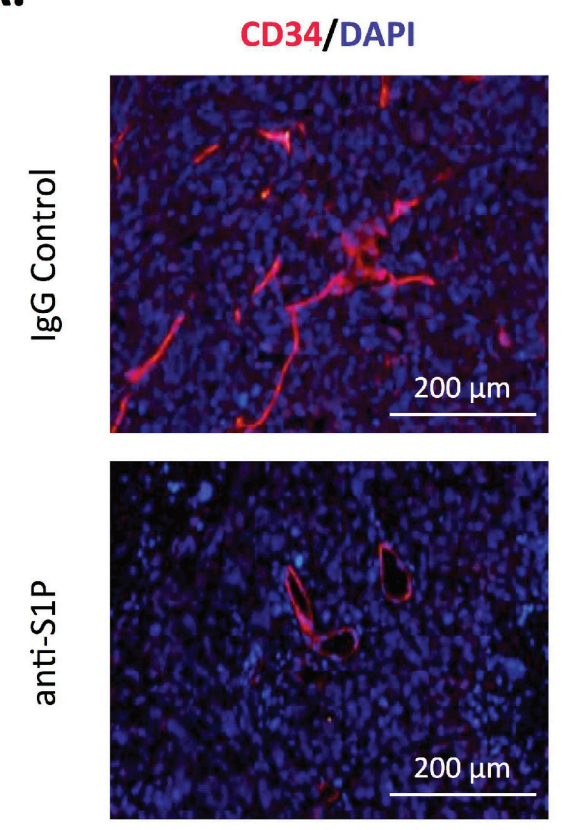

C.

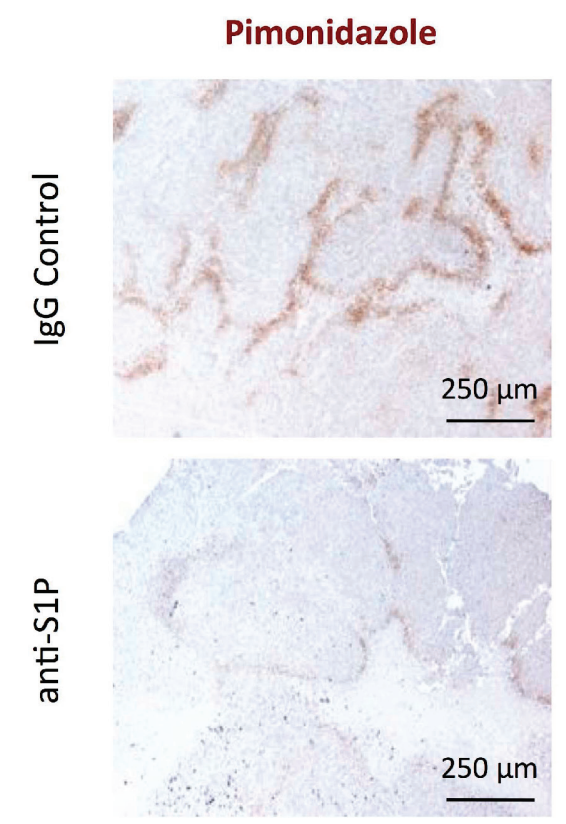

B.

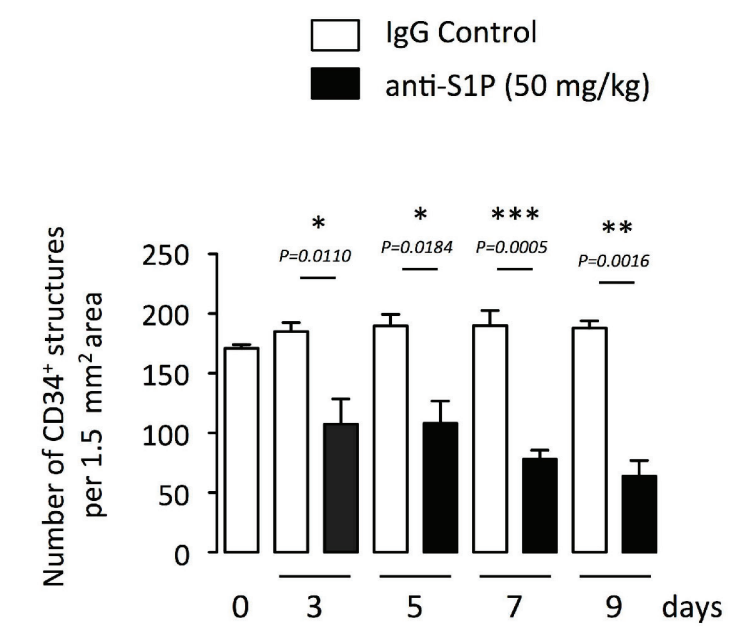

D.

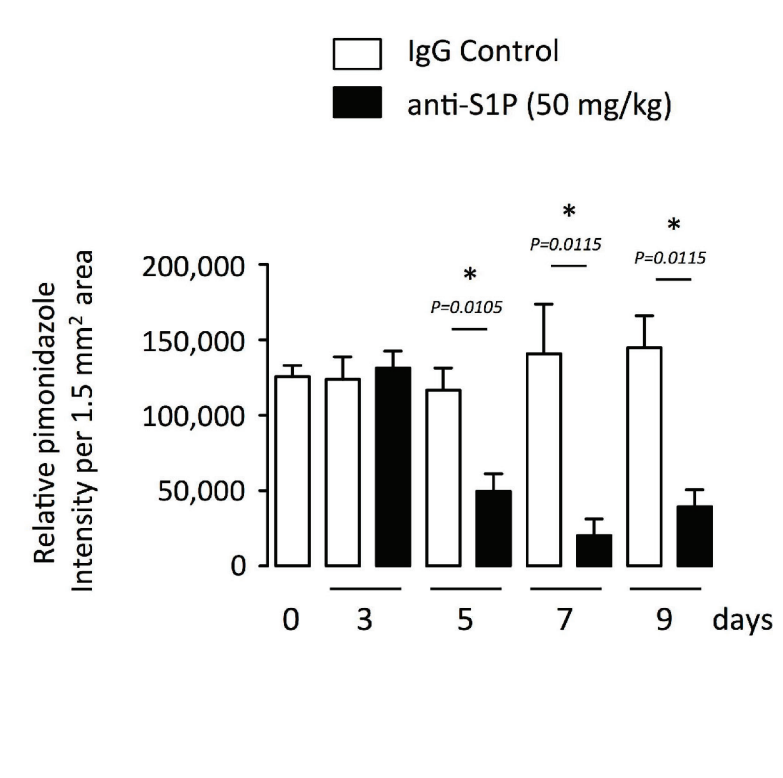

Figure 3: Effect of S1P neutralization on tumor vasculature and hypoxia in PC-3 tumor-bearing mice. (A) Representative images of blood vessel quantity and morphology in tumors after 5 days of treatment with $50 \mathrm{mg} / \mathrm{kg}$ anti-S1P mAb or IgG control. Tissue sections were stained with anti-CD34 (endothelial cell marker) antibody to visualize tumor blood vessel and were counterstained with DAPI. Scale bar, $200 \mu$ M. (B) Data are shown as number of CD34 structures per $1.5 \mathrm{~mm}^{2}$. Columns, mean of four mice per group; bars, SEM. (C) Hypoxia staining of representative regions of tumor sections from animals treated for 5 days with $50 \mathrm{mg} / \mathrm{kg}$ anti-S1P antibody or IgG control. Hypoxia was detected by immunohistochemistry staining of pimonidazole adducts in PC-3 tumor sections. Nuclear counterstain: hematoxylin staining. Scale bar, $250 \mu$ M. (D) Graph represents relative HypoxiaProbe intensity after 3, 5, 7 and 9 days of treatment with anti-S1P mAb or IgG control. Columns, mean of four mice per group; bars, SEM. 
A.
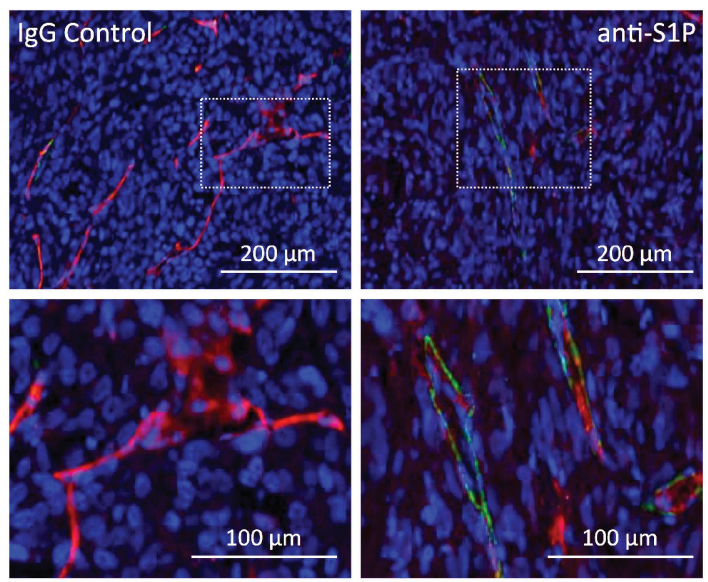

C.
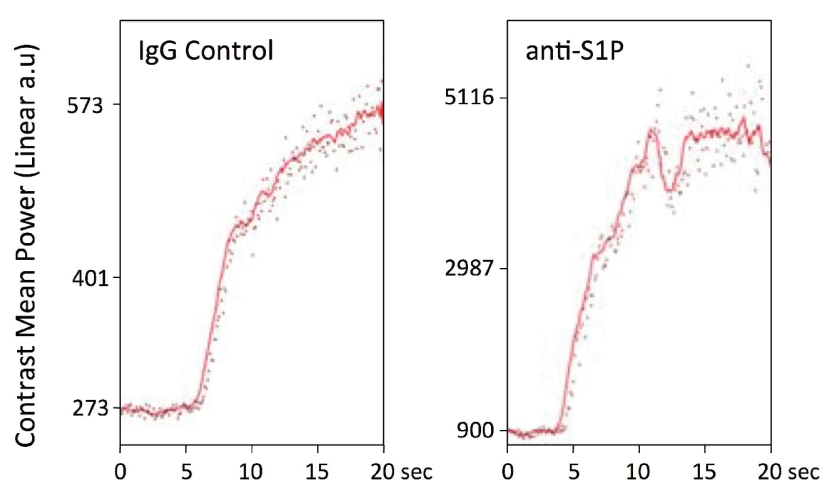

B.

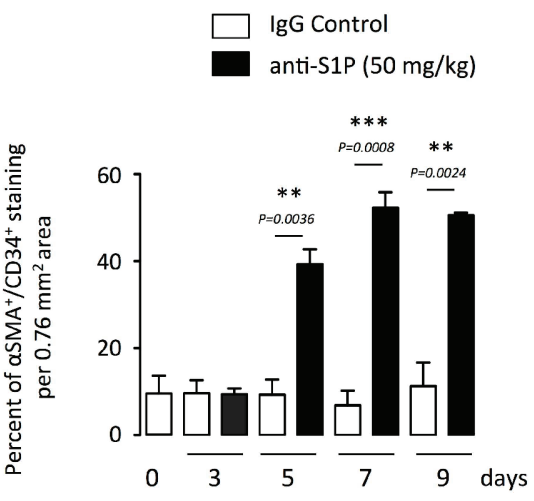

D.

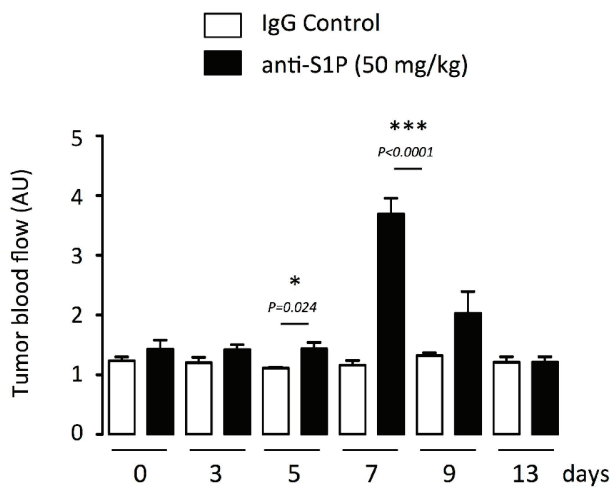

Figure 4: Effect of S1P neutralization on vessel functionality. (A) Representative images of immunofluorescence double staining for endothelial cells (CD34) and pericytes ( $\alpha$ SMA) in paraffin sections obtained from tumors of animals treated with $50 \mathrm{mg} / \mathrm{kg}$ anti-S1P $\mathrm{mAb}$ or IgG control. Red, CD34+ staining; green, $\alpha \mathrm{SMA}^{+}$staining. Counterstaining was done with DAPI. Images were obtained from mice 7 days after beginning of the treatment. Scale bar, $200 \mu \mathrm{M}$. (B) Graph represents quantification of vessel coverage per $0.76 \mathrm{~mm}^{2}$ area, calculated as the percentage of $\alpha$ SMA-positive cells compared with the number of CD34-positive cells after 3, 5, 7 and 9 days of treatment with $50 \mathrm{mg} / \mathrm{kg}$ anti-S1P mAb or IgG control. Columns, mean of four mice per group; bars, SEM. (C) Study of tumor vessel perfusion by contrast-enhanced ultrasound imaging. Examples of raw contrast kinetics acquired after bolus i.v. injection of microbubble contrast agent in animals treated with $50 \mathrm{mg} / \mathrm{kg} \mathrm{IgG}$ control or anti-S1P mAb for 7 days. (D) Quantification of microbubble velocity within o.t PC-3 tumors, after 3, 5, 7, 9 and 13 days of treatment with anti-S1P mAb or IgG control. Columns, mean of four mice per group; bars, SEM.

$\mathrm{mAb}$ (optimal time of 5 to 9 days) offers an opportunity for enhanced response to docetaxel, the standard of care for the treatment of metastatic prostate cancer [61, 62]. To this end, we relied on an orthotopic model of PC-3 cells overexpressing GFP, growing in their native milieu and leading to a local regional growth and spontaneous distant metastasis dissemination within five weeks that could be monitored by fluorescence imaging [56]. The therapeutic relevance of anti-S1P mAb-induced increase in transient vascular normalization (or oxygenation window) to docetaxel was investigated by varying the sequence of anti-S1P administration and chemotherapy (Figure 6A).

In the first therapeutic approach, tumor-bearing mice were treated with anti-S1P mAb $(50 \mathrm{mg} / \mathrm{kg}$ every other day) for a 5-day oxygenation window prior to $5 \mathrm{mg} /$ $\mathrm{kg}$ docetaxel (Arm 2) or with a classical combination of
anti-S1P mAb and docetaxel administered at the same time (Arm 3). Significantly smaller tumors $\left(\right.$ mean $\left.=455 \mathrm{~mm}^{3}\right)$ were seen in animals treated with $5 \mathrm{mg} / \mathrm{kg}$ docetaxel alone (Arm 5) (Figure 6B and 6C). Interestingly, administration of anti-S1P mAb alone (Arm 4) was not accompanied with a statistical reduction of primary tumor volume $\left(\right.$ mean $\left.=724 \mathrm{~mm}^{3}\right)$ as compared to IgG-treated control animal (Arm 1, mean $\left.=1010 \mathrm{~mm}^{3}\right)$ and the combination of S1P mAb with docetaxel administered at the same time $\left(\right.$ Arm 3, mean $=373 \mathrm{~mm}^{3}$ ) did not significantly sensitize to docetaxel alone (Arm 5) (Figure 6B and $6 \mathrm{C})$. Clearly, the greater effect on primary tumor growth occurred when anti-S1P mAb was administered 5 days before docetaxel treatment $\left(\right.$ Arm 2, mean $\left.=144 \mathrm{~mm}^{3}\right)$. Supporting the notion that chemotherapy response could be optimum when docetaxel is given when after vascular 
A.

\section{KI67/DAPI}
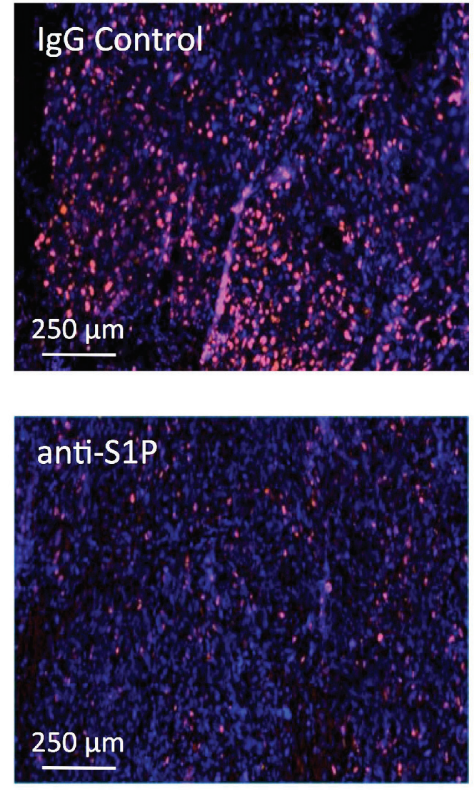

C. CASP-3/DAPI
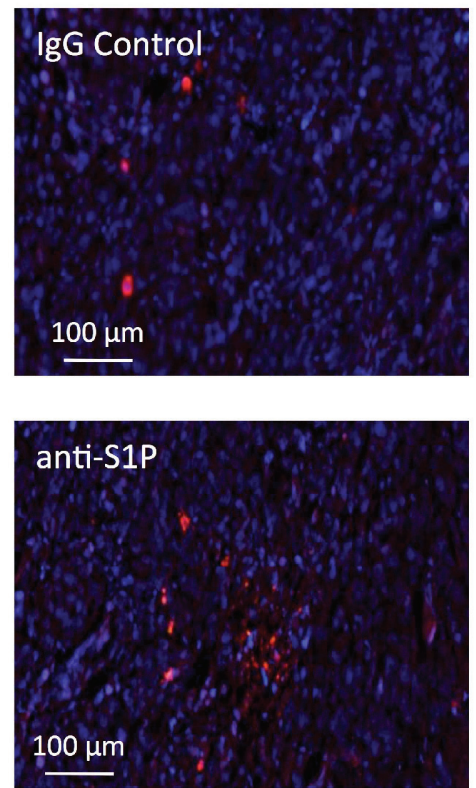

B.

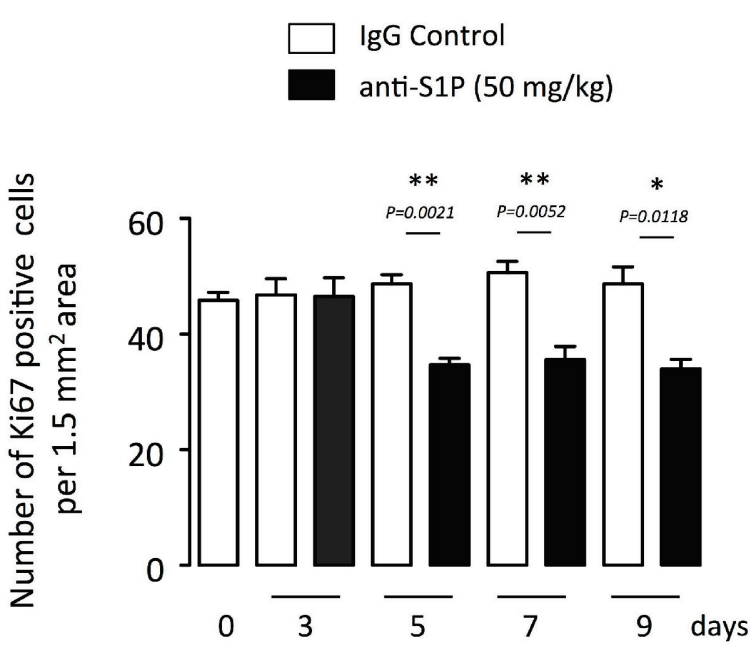

D.

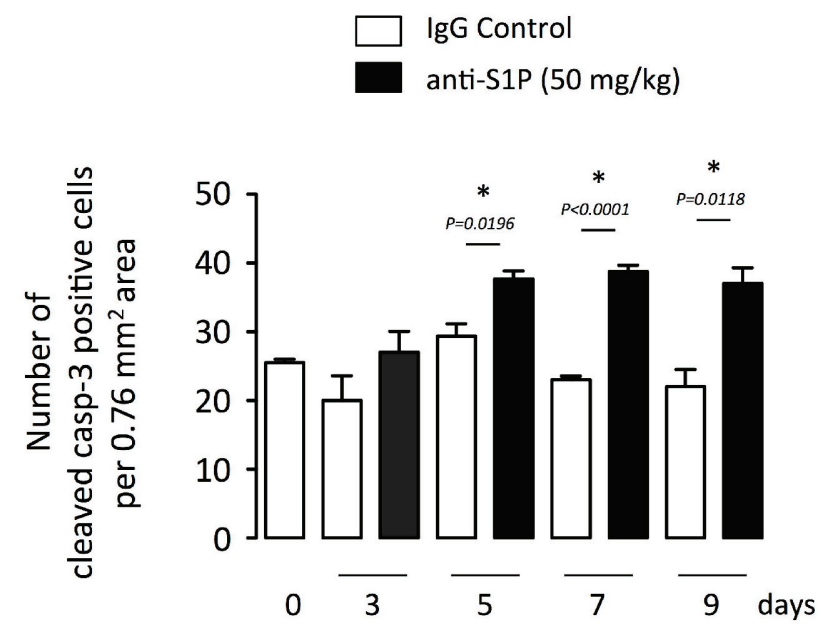

Figure 5: Effect of S1P neutralization on tumor cell proliferation and apoptosis of established orthotopic PC-3/GFP tumors in mice. (A) Ki67 staining of representative tumor sections after 7 days of treatment with $50 \mathrm{mg} / \mathrm{kg}$ anti-S1P mAb or IgG control. Red, Ki-67 positive staining. Counterstaining was done with DAPI. (B) Data are shown as number of Ki67-positive cells per $1.5 \mathrm{~mm}^{2}$ area after 3, 5, 7 and 9 days of treatment with anti-S1P mAb or IgG control. Columns, mean of four mice per group; bars, SEM. (C) Cleaved caspase-3 (CASP-3) staining of representative tumor sections after 7 days of treatment with $50 \mathrm{mg} / \mathrm{kg}$ anti-S1P mAb or IgG control. Red, cleaved caspase-3-positive staining. Counterstaining was done with DAPI. (D) Data are shown as number of cleaved caspase-3-positive cells per $0.76 \mathrm{~mm}^{2}$ area after 3, 5, 7 and 9 days of treatment with anti-S1P mAb or IgG control. Columns, mean of four mice per group; bars, SEM. 
A.

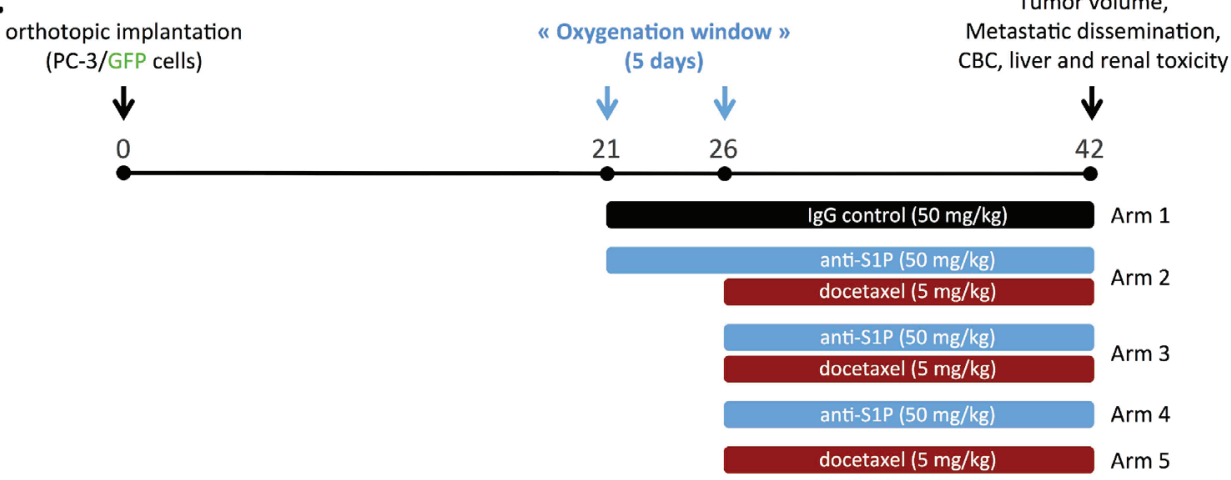

B.

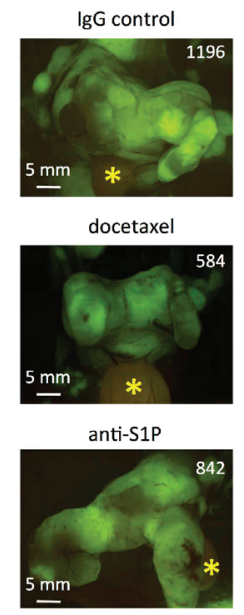

anti-S1P prior to docetaxel

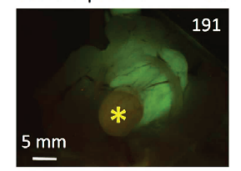

anti-S1P with docetaxel

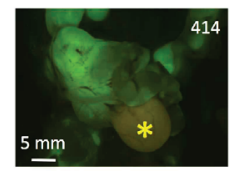

C.

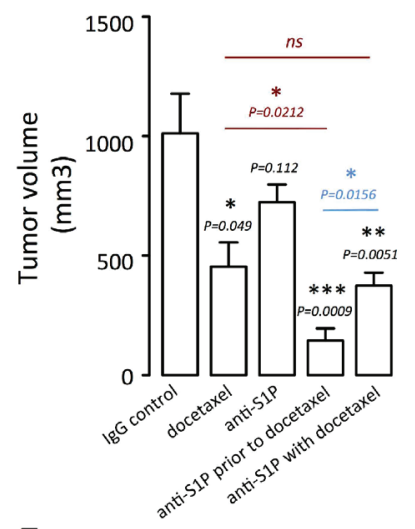

E.

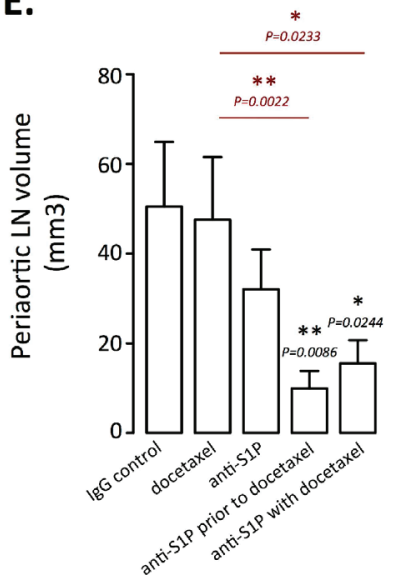

D.

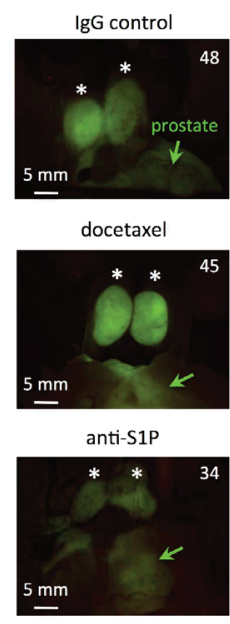

anti-S1P prior to docetaxel

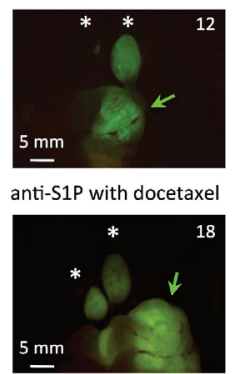

Figure 6: Docetaxel treatment enhancement by rational scheduling of S1P neutralization on established orthotopic PC-3/GFP tumors in mice. (A) Three weeks after surgical orthotopic implantation of PC-3/GFP cells, mice were randomized into five arms of three to seven animals each. These animals were then subjected to $50 \mathrm{mg} / \mathrm{kg} \mathrm{IgG} \mathrm{control} \mathrm{every} \mathrm{odd} \mathrm{day} \mathrm{(arm} \mathrm{1,} n=4) ; 50 \mathrm{mg} / \mathrm{kg}$ anti-S1P mAb every odd day prior to weekly $5 \mathrm{mg} / \mathrm{kg}$ docetaxel starting at day 26 (arm 2, $n=6$ ); combination of $50 \mathrm{mg} / \mathrm{kg}$ anti-S1P mAb

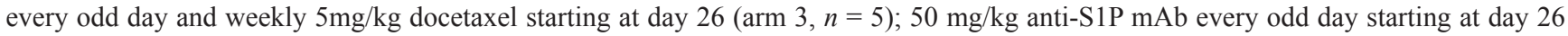
( $\operatorname{arm} 4, n=7$ ); weekly $5 \mathrm{mg} / \mathrm{kg}$ docetaxel starting at day 26 (arm 5,n=3). At day 42, mice were anesthetized and tumor volume, metastatic dissemination were determined by fluorescence imaging and blood was taken for complete blood count (CBC) and plasma chemistry. (B) Representative fluorescent primary PC-3/GFP tumors from animals treated with IgG control, docetaxel, anti-S1P mAb, anti-S1P mAb prior to docetaxel and combination of docetaxel and anti-S1P mAb, at the time of autopsy. Yellow asterisk indicates bladder. Numbers represent tumor volume as quantified in materials and methods. (C) Quantification of tumor volume of primary tumors. Columns, mean of three to seven mice per group; bars, SEM. (D) Representative fluorescent periaortic lymph nodes from animals treated with IgG control, docetaxel, anti-S1P mAb, anti-S1P mAb prior to docetaxel and combination of docetaxel and anti-S1P mAb, at the time of autopsy. Green arrows indicate prostate. Numbers represent periaortic lymph node volume as quantified in materials and methods. (E) Quantification of periaortic lymph nodes. Columns, mean of three to seven mice per group; bars, SEM. 
normalization is achieved by anti-S1P mAb treatment, we demonstrated in Figure 6 that a significant difference $(P=0.0156)$ was observed between Arm 2 (anti-S1P mAb prior to docetaxel) and Arm 3 (anti-S1P mAb coincident with docetaxel) (Figure $6 \mathrm{~B}$ and 6C). In addition to demonstrating an effect of antibody treatment on tumor volume, our fluorescent model allowed us to monitor metastatic dissemination in order to determine effects of the anti-S1P mAb on metastatic potential (Table 1). Although no treatment was able to significantly prevent lymph node tumor involvement (Table 1), we found a marked decreased in the volume of periaortic lymph nodes when anti-S1P mAb was combined to docetaxel (Figure 6D and 6E). As shown in Table 1, the anti-S1P $\mathrm{mAb}$ administration given before chemotherapy markedly reduced the total number of metastases (average per animal: 3.8) by comparison with isotype antibody controltreated Arm 1 (average per animal: 7.8). The effect of on primary tumor growth was thus consequently paralleled by a significant limitation of metastasis dissemination when anti-S1P mAb was given for 5 days before initiating chemotherapy.
To rule out that improved therapeutic outcome caused by the sequential dosing (Arm 2) was not a mere reflection of the longer administration of anti-S1P mAb when compared to the classical combination treatment without pre-treatment (Arm 3), a second therapeutic approach was conducted with additional scheduling conditions (Supplementary Figure 1A). Treatments were initiated at Day 21 rather than Day 26 and compared to the sequential normalization treatment (Arm 2). Surprisingly, starting docetaxel treatment earlier did not improve the efficacy with regard to tumor growth (Arm 6 versus Arm 5) (Supplementary Figure 1B). When docetaxel was given as early as 21 days post-implantation in combination with anti-S1P mAb (Arm 8), there was no significant difference in terms of therapeutic efficacy compared to the 26-day conditions (Arm 3), implying that an extra 5-day duration of treatment did not matter (Supplementary Figure 1B). Importantly, the sequential scheduling (Arm 2) was always superior to all the others (Arm 3 or Arm 8) in terms of therapeutic efficacy (Supplementary Figure 1B).

In sum, these data suggest mechanistically that the anti-S1P mAb treatment leads to improved chemotherapy

\section{Table 1: Pattern of metastatic dissemination}

\begin{tabular}{|c|c|c|c|c|c|}
\hline & IgG control & Docetaxel & anti-S1P & $\begin{array}{c}\text { anti-S1P \& } \\
\text { Docetaxel }\end{array}$ & $\begin{array}{c}\text { anti-S1P before } \\
\text { Docetaxel }\end{array}$ \\
\hline $\begin{array}{l}\text { No. of mice } \\
\text { with metastases/ } \\
\text { total No. of mice }\end{array}$ & $4 / 4(100 \%)$ & $\mathbf{3} / \mathbf{3}(100 \%)$ & $7 / 7(100 \%)$ & $\mathbf{5 / 5}(100 \%)$ & $\mathbf{5} / \mathbf{6}(83 \%)$ \\
\hline \multicolumn{6}{|l|}{$\begin{array}{l}\text { Retroperitoneal } \\
\text { lymph nodes }\end{array}$} \\
\hline $\begin{array}{l}\text { Periaortic lymph } \\
\text { nodes }\end{array}$ & $2,2,2,2$ & $2,2,1$ & $2,2,2,2,2,2,2$ & $1,2,2,2,2$ & $0,2,2,2,2,2$ \\
\hline Periadrenal & $2,2,2,1$ & $2,2,2$ & $2,2,2,2,1,1,1$ & $1,2,1,2,2$ & $0,1,1,2,1,1$ \\
\hline No. of metastases & $\begin{array}{c}\mathbf{1 5 / 1 6} \\
\text { (3.8 per animal) }\end{array}$ & $\begin{array}{c}\mathbf{1 1 / 1 2} \\
(3.7 \text { per animal) }\end{array}$ & $\begin{array}{c}\mathbf{2 5 / 2 8} \\
\text { (3.6 per animal) }\end{array}$ & $\begin{array}{c}\mathbf{1 7 / 2 0} \\
\text { (3.4 per animal) }\end{array}$ & $\begin{array}{c}\mathbf{1 6} / \mathbf{2 4} \\
\text { (2.6 per animal) }\end{array}$ \\
\hline \multicolumn{6}{|l|}{ Solid organs } \\
\hline Lung & $1,1,1,1$ & $1,1,1$ & $1,1,1,1,1,1,1$ & $1,1,1,1,1$ & $0,1,1,1,1,1$ \\
\hline Liver & $1,1,1,1$ & $0,1,1$ & $1,1,1,1,1,0,1$ & $1,1,1,0,1$ & $0,0,0,1,0,0$ \\
\hline Pancreas & $1,1,1,1$ & $1,1,1$ & $1,1,1,1,1,1,1$ & $1,1,1,0,0$ & $0,0,0,0,0,0$ \\
\hline Mesentery & $1,1,1,1$ & $0,1,1$ & $1,1,1,1,1,1,1$ & $1,1,1,0,0$ & $0,0,0,1,0,0$ \\
\hline No. of metastases & $\begin{array}{c}\mathbf{1 6 / 1 6} \\
\text { (4.0 per animal) }\end{array}$ & $\begin{array}{c}\mathbf{1 0} / \mathbf{1 2} \\
\text { (3.3 per animal) }\end{array}$ & $\begin{array}{c}\mathbf{2 7 / 2 8} \\
\text { (3.9 per animal) }\end{array}$ & $\begin{array}{c}\mathbf{1 5} / \mathbf{2 0} \\
\text { (3.0 per animal) }\end{array}$ & $\begin{array}{c}\mathbf{7 / 2 4} \\
\text { (1.2 per animal) }\end{array}$ \\
\hline $\begin{array}{l}\text { Total No. of } \\
\text { metastases }\end{array}$ & $\begin{array}{c}\mathbf{3 1} \\
\text { (7.8 per animal) }\end{array}$ & $\begin{array}{c}\mathbf{2 1} \\
\text { (7.0 per animal) }\end{array}$ & $\begin{array}{c}\mathbf{5 2} \\
\text { (7.4 per animal) }\end{array}$ & $\begin{array}{c}32 \\
\text { (6.4 per animal) }\end{array}$ & $\begin{array}{c}\mathbf{2 3} \\
\text { (3.8 per animal)* }\end{array}$ \\
\hline
\end{tabular}

For retroperitoneal lymph nodes, the numbers 0 , 1, or 2 represent the quantity of invaded lymph nodes. For solid organs, 0 means no presence of metastasis; 1 means a metastatic organ (regardless of the intensity of metastasis dissemination in this organ). The frequencies of metastases between two groups are not significant.

Differences in the number of metastases per mouse: $* P=0.0139$ compared with IgG control-treated animals (Wilcoxon Mann Whitney). 
response when administered for a short period of time before the commencement of chemotherapy, as a consequence of antibody-induced vascular normalization.

In addition to efficacy studies described above, we conducted a toxicology study at the end of the experiment described in Figure 6 designed to evaluate how well the antibody was tolerated in mice. All biochemical and complete blood count (CBC) and serum chemistry markers were within normal range (Supplementary Figures 2 and 3). A statistically significant leukopenia was noted only in mice treated with the combination of anti-S1P mAb and docetaxel, which was mainly the consequence of a significant reduction in total circulating lymphocytes as reported previously [23, 29, 63].

\section{DISCUSSION}

Hypoxia is a hallmark of solid tumors driving the production of angiogenic factors to establish a new vascular network $[35,37]$. In contrast to healthy tissues, hypoxia-triggered overexpression of VEGF and other pro-angiogenic factors in tumors leads to a structurally and functionally abnormal vasculature, which further aggravates hypoxia setting up a vicious cycle promoting tumorigenesis and metastatic potential [36, 37]. Anatomically, tumor vessels are dilated, tortuous, and saccular with chaotic patterns of interconnection and branching [64]. Unlike a normal vasculature where stable endothelial cells are connected by adherens junctions including vascular endothelial (VE)-cadherin [65], VEGF causes VE-cadherin destabilization hence a loosening of endothelial cell association [66]. Moreover, pericytes, normally positioned around and interacting with endothelial cells to prevent vessel leakage are absent or loosely attached $[67,68]$. The mechanisms for abnormal pericyte behavior in tumors are manifold, but include VEGF as a negative regulator $[69,70]$. Taken as a whole, the structural weaknesses of tumor vessels, by contributing to a porousness vasculature phenotype, have adverse consequences notably dissemination of tumor cells $[71,72]$ and impaired drug delivery and efficacy [39, 40]. For these reasons, strategies aimed at restoring tumor vasculature to a more normal state are a matter of the utmost importance as the improvement of vessel structure and function may delay progression and improve delivery and efficacy of chemotherapeutics [41]. Because VEGF is primarily accountable for this haphazard vasculature, it was hypothesized by Rakesh Jain that mopping up excess of VEGF, rather than destroying vessels, would prune away some abnormal vessels and remodel the remaining ones resulting in a more mature vasculature [73, 74]. Over the years, a wide array of preclinical [75-77] and clinical [78-81] studies have provided evidence to support this postulate, showing that judicious treatment with anti-VEGF agents results in transient enhancement of vascular function termed "vascular normalization" characterized by improved connection between adjacent endothelial cells, increased ratio of pericyte-covered vessels, improved association between endothelial cells and pericytes, and reduced hypoxia [41]. Importantly, the accompanying period of enhanced oxygenation known as the "normalization window", ranging in general from few days in mice models [41] to several weeks in some patients [81], corresponds to a period of enhanced chemo or radiosensitivity in treated tumors [40, 41, 75, 80]. Lastly, the most compelling support for the benefit of vascular normalization is its benefit on progression-free and overall survival rates in patients [81-84].

We recently identified the SphK1/S1P signaling as a new modulator of HIF-1 $\alpha$ accumulation and increased activity under hypoxia, through activation of the Akt/ GSK3 $\beta$ pathway $[50,85]$. It was recently reported that direct addition of S1P to thyroid cancer cells stimulate Akt signaling under normoxic conditions [86]. Because Akt is activated by Gi-coupling of all subtypes of GPCR S1P receptors [10], and because $\mathrm{S} 1 \mathrm{P}$ is secreted by hypoxic cells $[51,52]$, we analyzed the effects of the neutralization of extracellular S1P with the anti-S1P mAb, sphingomab [15]. Here we report for the first time that sphingomab inhibits HIF- $1 \alpha$ accumulation and activity under hypoxia in various cell models (prostate, lung, glioma). This was a consequence of the secretion of S1P by hypoxic cells since knock-down of the S1P transporter Spns2 blocked the activation of HIF$1 \alpha$, an effect that was reversed by the addition of S1P.

In an orthotopic prostate cancer animal model, we characterized the time course of morphological and functional changes in the vasculature of the tumor as well as intratumoral hypoxia in response to treatment with sphingomab. We demonstrated that S1P neutralization created a less hypoxic environment as shown by the marked decreased in HIF-1 $\alpha$ expression and activity (concomitant decrease in GLUT-1 expression), and secretion of VEGF from the tumor. As a result, vascular remodelling occurred as demonstrated by decreased microvessel density and vessel morphological changes namely increased coverage of pericytes. As previously reported for anti-VEGF strategies in other preclinical models [75-77], the anti-S1P mAb was able to normalize intratumoral vasculature after a period (from 5 to 9 days) of treatment. Measurements of tumor blood flow and perfusion assessed by high resolution 3-dimensional power Doppler ultrasound [57, 58] demonstrated a transient improvement in tumor perfusion. Finally and most importantly, we established that the transient vascular normalization window induced by sphingomab created an optimal time frame for the administration of docetaxelbased chemotherapy with enhanced efficacy. Indeed, the therapeutic relevance of sphingomab-induced increases in tumor oxygenation to chemotherapy was investigated by varying the schedules of sphingomab and chemotherapy. Clearly, a greater benefit on both primary tumor and metastasis dissemination took place when sphingomab was administered 5 days prior docetaxel treatment. 
Interestingly S1P has originally been shown to stabilize blood vessels in development and homeostasis through $\mathrm{S} 1 \mathrm{P}$ receptor subtype $1\left(\mathrm{~S}_{1} \mathrm{P}_{1}\right)$ by promoting the formation of VE-cadherin-containing adherens junctions in endothelial cells $[21,87,88]$. Supporting this notion, the loss $\mathrm{S}_{1} \mathrm{P}_{1}$ in retinal endothelial cells results in vessels displaying poor blood flow and vascular leakage [89]. In addition, vessel coverage by pericytes is also directed by the activity of $\mathrm{S}_{1} \mathrm{P}_{1}$ receptor in endothelial cells [90, $91]$ by trafficking and activating $\mathrm{N}$-cadherin involved in endothelial cell/pericyte interactions [92]. Our findings that neutralization of exogenous S1P with sphingomab leads to vascular maturation in hypoxic tumors are somehow counterintuitive to the undisputed role of $\mathrm{S}_{1} \mathrm{P}_{1}$, one of its main cognate receptor. Surprisingly it has been reported that S1P could increase vascular permeability similar to VEGF, the canonical vascular permeability factor [93]. The mechanism of action would involve the activation of the $\mathrm{S}_{1} \mathrm{P}_{2}$ subtype $\mathrm{S} 1 \mathrm{P}$ receptor. This observation was extended to in vivo model of vascular permeability in the rat lung, in which the $\mathrm{S}_{1} \mathrm{P}_{2}$ antagonist JTE013 significantly inhibited $\mathrm{H}_{2} \mathrm{O}_{2}$-induced permeability [93]. In vitro and in vivo models of inflammation-induced vascular permeability confirmed the role of $\mathrm{S}_{1} \mathrm{P}_{2}$ [94]. These studies indicate that the relative expression of $\mathrm{S} 1 \mathrm{P}_{1}$ and $\mathrm{S} 1 \mathrm{P}_{2}$ receptors in a specific vascular bed would determine the response to $\mathrm{S} 1 \mathrm{P}$. Noteworthy, in vivo studies have shown that $\mathrm{S}_{2} \mathrm{P}_{2}$ expression is markedly enhanced under hypoxic stress in pathological angiogenesis of the mouse retina, establishing its essential role in pathological neovascularization [95]. Further supporting a critical role for $\mathrm{S}_{1} \mathrm{P}_{2}$ signaling in mediating vascular permeability, the addition of exogenous $\mathrm{S} 1 \mathrm{P}$ to normoxic endothelial cells also induce the activation of HIF-1 $\alpha$ and subsequent rise in VEGF release, suggesting a potential amplification of VEGF signaling [96]. Lastly, S1P 2 -deficient (S1p2-/-) mice implanted with lung or melanoma cells displayed increased number of maturated and functional tumor vessels, showing increased pericyte coverage [97]. In summary, one might speculate that the balance between $\mathrm{S}_{1} \mathrm{P}_{1}$ and $\mathrm{S} 1 \mathrm{P}_{2}$ receptors in the endothelium could be modified by hypoxia, with a shift toward higher $\mathrm{S}_{1} \mathrm{P}_{2}$ expression hence increasing vascular permeability. Neutralization of S1P produced by hypoxic tumor cells by sphingomab could have a direct impact on vessels by switching off $\mathrm{S}_{2} \mathrm{P}_{2}$-mediated vascular leakage, a mechanism reminiscent of the effect of bevacizumab on VEGF. In addition, neutralization of S1P through inhibition of HIF- $1 \alpha$ could impact the cancer cell compartment by reducing intratumoral hypoxia and its undesirable consequences (including VEGF overproduction), while sensitizing tumor cells to cytotoxic agents as S1P is a wellestablish anti-apoptotic agent [5].

The extent of intratumoral hypoxia seen in the prostate cancer context is comparable to that seen in other cancers [98]. Since the seminal study conducted by Folkman's group showing that angiogenesis correlates with metastasis in invasive prostate cancer [99], numerous reports have confirmed an association between prostate cancer aggressiveness and increased microvessel density, greater irregularity of the vessel lumen and smaller vessels [100]. In a prostatectomy cohort of patients $(n=572)$ with clinically localized prostate cancer with 20 years of followup, men with the most irregularly shaped vessels were 17.1 times more likely to develop lethal disease several years after diagnosis [101]. These data clearly suggest that the morphologic characteristics that reflect the pattern and maturity of the growing vascular network could represent valid indicators of neoangiogenesis, cancer aggressiveness, and metastatic potential in prostate. In patients with metastatic castration-resistant prostate cancer, VEGF levels are independent predictors of overall survival [102]. These data supported the hypothesis that VEGF inhibition may enhance current therapies in metastatic prostate cancer. However, the failure of two recently published phase III trials $[103,104]$ based on combination regimens associating docetaxel with anti-VEGF strategies (bevacizumab or aflibercept) underline our limited understanding of the therapeutic targets being explored and poor preclinical investigation. No preclinical data to lend support to the combination of docetaxel and anti-VEGF approaches have been reported in the literature, and the vast majority of phase II trials have used non-randomized designs [105]. Despite the fact that these large trials have produced disappointing results with docetaxel-based combined antiVEGF therapies, the notion that reduction of hypoxia and improvement of functional vascularization could sensitize to a therapeutic regimen has been successfully suggested in prostate cancer. Evidence exists that diminution of intratumoral hypoxia [106, 107], reduction of VEGF production [108] and improved functional vascularization [109] during androgen deprivation (ADT) would be accountable for the improved clinical outcome and patient survival observed in phase III clinical trials of short-term neoadjuvant ADT before radiotherapy $[110,111]$.

In view of these data supporting that only a neoadjuvant approach (ADT) could successfully sensitize to a therapy in prostate cancer, our preclinical findings may have clinical implications. Improvement in blood perfusion leading to better drug delivery or increased tumor oxygenation offers a rationale as to why S1P neutralization might perhaps be started prior to cytotoxic therapy (chemo- or radiotherapy) and continued through this therapy. Non-invasive imaging techniques are currently available in the clinic that could be used to assess tumor vascularity (i.e. DCE MRI) and/or oxygenation such as PET scanning with hypoxia sensitive tracers [79, 81, 82, $84,109]$. Hence, our findings encourage further clinical studies to assess whether optimized scheduling of antiS1P treatment provide evidence for vessel normalization in cancer patients to identify those who might be benefit from a combination therapy with cytotoxic agents or radiotherapy. 


\section{MATERIALS AND METHODS}

\section{Chemicals, reagents and kits}

Culture medium and serum were from Invitrogen (Villebon sur Yvette, France). The murine monoclonal anti-S1P antibody, Sphingomab, and its isotype-matched $\mathrm{mAb}$ control, LT1017, were generated as described previously [29]. S1P was from Avanti Polar Lipids (Alabaster, AL). Docetaxel was purchased from SigmaAldrich (St. Louis, MO). hVEGF plasma levels were quantified using a human VEGF Quantikine ELISA kit (R $\alpha$ D systems, Lille, France) according to manufacturer's instructions, respectively.

\section{Cell lines}

Human prostate cancer PC-3 and lung carcinoma A549 cell lines were obtained from DSMZ (Braunschweig, Germany). Human U87 glioblastoma cells were from ATCC-LGC Standards (Molsheim, France). Cells were cultured in RPMI 1640 containing 10\% fetal bovine serum at $37^{\circ} \mathrm{C}$ in $5 \% \mathrm{CO}_{2}$ humidified incubators. Cell lines were routinely verified by the following tests: morphology microscopic examination, growth curve analysis and mycoplasma detection (MycoAlert ${ }^{\mathrm{TM}}$, Lonza, Basel, Switzerland). All experiments were started with low-passaged cells ( $<15$ times). Hypoxia $\left(0.1 \% \mathrm{O}_{2}, 5 \%\right.$ $\mathrm{CO}_{2}, 94.5 \% \mathrm{~N}_{2}$ ) was achieved using an In Vivo hypoxic workstation (Ruskinn Technologies, Bridgend, UK).

\section{siRNA-mediated knockdown of Spns2}

Cancer cells were transfected with $90 \mathrm{nM}$ of each specific MISSION predesigned small interfering RNA (siRNA, Sigma-Aldrich) using Lipofectamine 2000 reagent (Invitrogen) according to the manufacturer's instructions. Aleatory sequence scrambled siRNA was from Eurogentec (Angers, France). Details of each specific MISSION predesigned siRNAs are provided below: human Spns2 siRNAa: 5'-CGCUCAUGCUCUGCCCU UUdTdT-3'; and human Spns2 siRNAb: 5'-CACUCAUC CUCAUUCUGGUdTdT-3'.

\section{Western-blot analysis and antibodies}

Mouse HIF-1 $\alpha$ (BD Biosciences, Le Pont de Claix, France), rabbit anti-Spns2 (Sigma-Aldrich) were used as primary antibodies. Western blot assays were conducted according to the manufacturer's instructions. Proteins were visualized by enhanced chemiluminescence detection system (Pierce, Brebières, France) using antirabbit or antimouse horseradish peroxidase-conjugated IgG (Bio-Rad, Hercules, CA). Equal loading was confirmed by probing the blots with the mouse anti-tubulin antibody (Sigma-Aldrich, clone DM1A). Densitometry quantitation was determined using Image J software (NIH, Bethesda, MD).

\section{Animals}

Male NMRI/Nu (nu/nu) 6-wk-old mice were obtained from Elevage Janvier (Le Genest Saint Isle, France). Mice were housed in a barrier facility of highefficiency particulate air-filtered racks. At 7-8 wk of age, the animals were used in accordance with the principles and procedures outlined in Council Directive 86/809/ EEC. The Institut Fédératif de Recherche Bio-médicale de Toulouse Animal Care and Use Committee approved all animal studies.

\section{Blood and plasma samples}

Blood samples were analysed using the $\mathrm{ABX}$ Micros 60 Hematology Analyzer and analytical parameters were determined in plasma by routine laboratory methods using an autoanalyzer (Cobas Mira+), Plateforme phenotypage ANEXPLO (Toulouse, France).

\section{Immunohistochemistry and immunofluorescence}

Staining was conducted on paraformaldehyde (PFA)-fixed and paraffin-embedded tissue using $5 \mu \mathrm{m}$ sections. Intratumoral hypoxia was assessed using a commercially available Hypoxyprobe ${ }^{\mathrm{TM}}-1$ kit for the detection of tissue hypoxia (Hypoxyprobe Inc., Burlington, MA). Pimonidazole hydrochloride was given at a dose of $60 \mathrm{mg} / \mathrm{kg}$ in $0.9 \%$ saline via intraperitoneal injection one hour before euthanasia, and orthotopic tumors were harvested and fixed in 4\% PFA. Details regarding antibodies, dilutions, and antigen-retrieval methods used are provided in Supplementary Table S1.

\section{Orthotopic implantation of PC-3/GFP prostate cancer cells, and in vivo fluorescence imaging}

Intraprostatic human prostate cancer xenografts were established in nude mice by surgical orthotopic implantation. Mice were anesthetized by isoflurane inhalation and placed in the supine position. A lower midline abdominal incision was made, and a $20 \mu \mathrm{L}$ tumor cell suspension ( $1 \times 10^{6}$ cells) was injected into the dorsal lobe of the prostate using a 30-gauge needle and glass syringe. The surgical wound was closed in 2 layers with 4-0 Dexon interrupted sutures. All procedures were performed with a dissecting microscope. Autopsy and in vivo fluorescence imaging were conducted as previously detailed [56].

\section{Tumor vessel perfusion by contrast-enhanced ultrasound imaging}

Optical and ultrasound/power Doppler were carried out under anaesthesia ( $2 \%$ isofluorane in oxygen). Microbubble contrast agents were used to enhance in vivo visualization of microvascular perfusion of the tumors. 
This was operated with a Vevo 2100 linear array based high-frequency ultrasound imaging system (VisualSonics, Amsterdam, The Netherlands) and subsequent release of Nonlinear Contrast Imaging Mode. This allowed to assess the tumoral responses to anti-angiogenic drugs, even in absence of change in tumor size. The Micromarker Contrast Agent was delivered as a bolus injection intravenously (tail), and a time versus intensity curve is generated. The perfusion curve kinetics is an exponential limited by a maximum. The initial slope is proportional to the flow velocity and the maximum value of the plateau is proportional to the vascular fractional volume. The product of these two values gives a measure of the true perfusion. The perfusion model is defined as:

$\mathrm{O}, \mathrm{A}, \mathrm{m}$ and $\mathrm{s}$ are fitting parameters; $\mathrm{O}$ is the offset, $\mathrm{A}$ is an amplitude parameter and $\mathrm{m}$ and $\mathrm{s}$ are the mean and standard deviation of the normally distributed natural logarithm of $\mathrm{t}$, respectively. Amplitude is expressed relative to echo power, time is expressed in seconds and both are combined to produce quantities relating to blood flow kinetics.

After infusion and steady-state perfusion, a destructive pulse could also be applied and a replenishment curve was generated.

The perfusion model is defined as:

where $\mathrm{O}, \mathrm{A}, \mathrm{m}$ and $\mathrm{s}$ are fitting parameters, as defined for equation 1 .

\section{Image acquisition and processing and quantification}

For bright-field and fluorescence, slides were scanned with Nanozoomer 2.0 RS Hamamatsu (with the fluorescence imaging module for tumor slides stained with anti-CD34, anti- $\alpha$ SMA, anti-cleaved-caspase-3, or antiKi67). Absolute numbers of CD34-positive vessels present within $1.5 \mathrm{~mm}^{2}$ of the tumor area and percent of $\alpha \mathrm{SMA} /$ CD34-positive staining per $0.76 \mathrm{~mm}^{2}$ area and number of HIF-1 $\alpha$-positive cells per $0.8 \mathrm{~mm}^{2}$ area for each tumor slide were quantified by optical counting. Automatic cell counts of Ki67-positive and cleaved caspase-3-positive cells and automatic GLUT-1 and pimonidazole intensity were determined per $1.5 \mathrm{~mm}^{2}$ of the tumor area with Image J Software (NIH, Bethesda, MD).

\section{Statistical analysis}

The statistical significance of differences between the means of two groups was evaluated by unpaired
Student's $t$ test. The frequencies of metastases between two groups were compared using Fisher's exact test. Differences in the number of metastases per mouse were examined using a nonparametric Wilcoxon - Mann Whitney test. All statistical tests were two-sided and the level of significance was set at $P<0.05$. Calculations were done using Instat (GraphPad Software, San Diego, CA).

\section{ACKNOWLEDGMENTS}

We are grateful to Dr Nathalie Ortega and Dr Leonor Nogueira for their technical help. We thank the Institut de Pharmacologie et de Biologie Structurale histology facilities.

This work was supported by the Institut National du Cancer (Sphingoxia project to OC), the Ligue Nationale Contre le Cancer (Equipe Labellisée LIGUE 2011 to OC), the Association pour la Recherche sur le Cancer (ARC Grant 1029 to OC), the Equipment ARC Grant (ECL2010R00650 to OC), the Association pour la Recherche sur les Tumeurs de la Prostate (to OC), the Comité Haute-Garonne of the Ligue Contre le Cancer (to IA), Université Paul Sabatier de Toulouse (to IA), the Association Française d'Urologie (to BM). This work was also supported by the National Cancer Institute (5R44CA110298-06 to RAS).

\section{CONFLICTS OF INTEREST}

Authors would like to disclose that Dr. Roger A. Sabbadini is a founder of Lpath, and has stock in the company and is an inventor.

\section{REFERENCES}

1. Pyne NJ, Pyne S. Sphingosine 1-phosphate and cancer. Nat Rev Cancer. 2010; 10:489-503.

2. Pitson SM. Regulation of sphingosine kinase and sphingolipid signaling. Trends Biochem Sci. 2011; 36:97-107.

3. Maceyka M, Harikumar KB, Milstien S, Spiegel S. Sphingosine-1-phosphate signaling and its role in disease. Trends Cell Biol. 2012; 22:50-60.

4. Mendelson K, Evans T, Hla T. Sphingosine 1-phosphate signalling. Development. 2014; 141:5-9.

5. Cuvillier O, Pirianov G, Kleuser B, Vanek PG, Coso OA, Gutkind S, Spiegel S. Suppression of ceramide-mediated programmed cell death by sphingosine-1-phosphate. Nature. 1996; 381:800-803.

6. Olivera A, Kohama T, Edsall L, Nava V, Cuvillier O, Poulton S, Spiegel S. Sphingosine kinase expression increases intracellular sphingosine-1-phosphate and promotes cell growth and survival. J Cell Biol. 1999; 147:545-558. 
7. Kawahara A, Nishi T, Hisano Y, Fukui H, Yamaguchi A, Mochizuki N. The sphingolipid transporter spns2 functions in migration of zebrafish myocardial precursors. Science. 2009; 323:524-527.

8. Fukuhara S, Simmons S, Kawamura S, Inoue A, Orba Y, Tokudome T, Sunden Y, Arai Y, Moriwaki K, Ishida J, Uemura A, Kiyonari H, Abe T, et al. The sphingosine1-phosphate transporter Spns2 expressed on endothelial cells regulates lymphocyte trafficking in mice. J Clin Invest. 2012; 122:1416-1426.

9. Nagahashi M, Kim EY, Yamada A, Ramachandran S, Allegood JC, Hait NC, Maceyka M, Milstien S, Takabe K, Spiegel S. Spns2, a transporter of phosphorylated sphingoid bases, regulates their blood and lymph levels, and the lymphatic network. FASEB J. 2013; 27:1001-1011.

10. Takabe K, Paugh SW, Milstien S, Spiegel S. "Inside-out" signaling of sphingosine-1-phosphate: therapeutic targets. Pharmacol Rev. 2008; 60:181-195.

11. Van Brocklyn JR, Lee MJ, Menzeleev R, Olivera A, Edsall L, Cuvillier O, Thomas DM, Coopman PJ, Thangada S, Liu CH, Hla T, Spiegel S. Dual actions of sphingosine-1-phosphate: extracellular through the Gi-coupled receptor Edg-1 and intracellular to regulate proliferation and survival.J Cell Biol. 1998; 142:229-240.

12. Hait NC, Allegood J, Maceyka M, Strub GM, Harikumar KB, Singh SK, Luo C, Marmorstein R, Kordula T, Milstien S, Spiegel S. Regulation of histone acetylation in the nucleus by sphingosine-1-phosphate. Science. 2009; 325:1254-1257.

13. Alvarez SE, Harikumar KB, Hait NC, Allegood J, Strub GM, Kim EY, Maceyka M, Jiang H, Luo C, Kordula T, Milstien S, Spiegel S. Sphingosine-1-phosphate is a missing cofactor for the E3 ubiquitin ligase TRAF2. Nature. 2010; 465:1084-1088.

14. Cuvillier O. Downregulating sphingosine kinase-1 for cancer therapy. Expert Opin Ther Targets. 2008; 12:1009-1020.

15. Sabbadini RA. Sphingosine-1-phosphate antibodies as potential agents in the treatment of cancer and agerelated macular degeneration. Br J Pharmacol. 2011; 162:1225-1238.

16. Pyne S, Pyne NJ. Translational aspects of sphingosine 1-phosphate biology. Trends Mol Med. 2011; 17:463-472.

17. Van Brocklyn JR, Jackson CA, Pearl DK, Kotur MS, Snyder PJ, Prior TW. Sphingosine kinase-1 expression correlates with poor survival of patients with glioblastoma multiforme: roles of sphingosine kinase isoforms in growth of glioblastoma cell lines. J Neuropathol Exp Neurol. 2005; 64:695-705.

18. Ruckhaberle E, Rody A, Engels K, Gaetje R, von Minckwitz G, Schiffmann S, Grosch S, Geisslinger G, Holtrich U, Karn T, Kaufmann M. Microarray analysis of altered sphingolipid metabolism reveals prognostic significance of sphingosine kinase 1 in breast cancer. Breast Cancer Res Treat. 2008; 112:41-52.
19. Li J, Guan HY, Gong LY, Song LB, Zhang N, Wu J, Yuan J, Zheng YJ, Huang ZS, Li M. Clinical significance of sphingosine kinase-1 expression in human astrocytomas progression and overall patient survival. Clin Cancer Res. 2008; 14:6996-7003.

20. Li W, Yu CP, Xia JT, Zhang L, Weng GX, Zheng HQ, Kong QL, Hu LJ, Zeng MS, Zeng YX, Li M, Li J, Song LB. Sphingosine kinase 1 is associated with gastric cancer progression and poor survival of patients. Clin Cancer Res. 2009; 15:1393-1399.

21. Lee MJ, Thangada S, Claffey KP, Ancellin N, Liu CH, Kluk M, Volpi M, Sha'afi RI, Hla T. Vascular endothelial cell adherens junction assembly and morphogenesis induced by sphingosine-1-phosphate. Cell. 1999; 99:301-312.

22. Chae SS, Paik JH, Furneaux H, Hla T. Requirement for sphingosine 1-phosphate receptor-1 in tumor angiogenesis demonstrated by in vivo RNA interference. J Clin Invest. 2004; 114:1082-1089.

23. Visentin B, Vekich JA, Sibbald BJ, Cavalli AL, Moreno KM, Matteo RG, Garland WA, Lu Y, Yu S, Hall HS, Kundra V, Mills GB, Sabbadini RA. Validation of an anti-sphingosine-1-phosphate antibody as a potential therapeutic in reducing growth, invasion, and angiogenesis in multiple tumor lineages. Cancer Cell. 2006; 9:225-238.

24. Anelli V, Gault CR, Snider AJ, Obeid LM. Role of sphingosine kinase-1 in paracrine/transcellular angiogenesis and lymphangiogenesis in vitro. FASEB J. 2010; 24:2727-2738.

25. Pchejetski D, Doumerc N, Golzio M, Naymark M, Teissie J, Kohama T, Waxman J, Malavaud B, Cuvillier O. Chemosensitizing effects of sphingosine kinase-1 inhibition in prostate cancer cell and animal models. Mol Cancer Ther. 2008; 7:1836-1845.

26. Paugh SW, Paugh BS, Rahmani M, Kapitonov D, Almenara JA, Kordula T, Milstien S, Adams JK, Zipkin RE, Grant S, Spiegel S. A selective sphingosine kinase 1 inhibitor integrates multiple molecular therapeutic targets in human leukemia. Blood. 2008; 112:1382-1391.

27. Kapitonov D, Allegood JC, Mitchell C, Hait NC, Almenara JA, Adams JK, Zipkin RE, Dent P, Kordula T, Milstien S, Spiegel S. Targeting sphingosine kinase 1 inhibits Akt signaling, induces apoptosis, and suppresses growth of human glioblastoma cells and xenografts. Cancer Res. 2009; 69:6915-6923.

28. Pchejetski D, Boehler T, Brizuela L, Sauer L, Doumerc N, Golzio M, Salunkhe V, Teissie J, Malavaud B, Waxman J, Cuvillier O. FTY720 (Fingolimod) sensitizes prostate cancer cells to radiotherapy by inhibition of sphingosine kinase-1. Cancer Res. 2010; 70:8651-8661.

29. O'Brien N, Jones ST, Williams DG, Cunningham HB, Moreno K, Visentin B, Gentile A, Vekich J, Shestowsky W, Hiraiwa M, Matteo R, Cavalli A, Grotjahn D, et al. Production and characterization of monoclonal antisphingosine-1-phosphate antibodies. J Lipid Res. 2009; 50:2245-2257. 
30. Ponnusamy S, Selvam SP, Mehrotra S, Kawamori T, Snider AJ, Obeid LM, Shao Y, Sabbadini R, Ogretmen B. Communication between host organism and cancer cells is transduced by systemic sphingosine kinase 1/sphingosine 1-phosphate signalling to regulate tumour metastasis. EMBO Mol Med. 2012; 4:761-775.

31. Brizuela L, Martin C, Jeannot P, Ader I, Gstalder C, Andrieu G, Bocquet M, Laffosse JM, GomezBrouchet A, Malavaud B, Sabbadini RA, Cuvillier O. Osteoblast-derived sphingosine 1-phosphate to induce proliferation and confer resistance to therapeutics to bone metastasis-derived prostate cancer cells. Mol Oncol. 2014; 8:1181-1195.

32. Semenza GL. Hypoxia-inducible factors in physiology and medicine. Cell. 2012; 148:399-408.

33. Vaupel P, Mayer A. Hypoxia in cancer: significance and impact on clinical outcome. Cancer Metastasis Rev. 2007; 26:225-239.

34. Carmeliet P. Angiogenesis in life, disease and medicine. Nature. 2005; 438:932-936.

35. Semenza GL. Hypoxia-inducible factor 1 and cancer pathogenesis. IUBMB Life. 2008; 60:591-597.

36. Jain RK. Normalization of tumor vasculature: an emerging concept in antiangiogenic therapy. Science. 2005; 307:58-62.

37. Carmeliet P, Jain RK. Principles and mechanisms of vessel normalization for cancer and other angiogenic diseases. Nat Rev Drug Discov. 2011; 10:417-427.

38. Padera TP, Stoll BR, Tooredman JB, Capen D, di Tomaso E, Jain RK. Pathology: cancer cells compress intratumour vessels. Nature. 2004; 427:695.

39. Tredan O, Galmarini CM, Patel K, Tannock IF. Drug resistance and the solid tumor microenvironment. J Natl Cancer Inst. 2007; 99:1441-1454.

40. Maity A, Bernhard EJ. Modulating tumor vasculature through signaling inhibition to improve cytotoxic therapy. Cancer Res. 2010; 70:2141-2145.

41. Goel S, Duda DG, Xu L, Munn LL, Boucher Y, Fukumura D, Jain RK. Normalization of the vasculature for treatment of cancer and other diseases. Physiol Rev. 2011; 91:1071-1121.

42. Wang GL, Jiang BH, Rue EA, Semenza GL. Hypoxiainducible factor 1 is a basic-helix-loop-helix-PAS heterodimer regulated by cellular O2 tension. Proc Natl Acad Sci U S A. 1995; 92:5510-5514.

43. Majmundar AJ, Wong WJ, Simon MC. Hypoxia-inducible factors and the response to hypoxic stress. Mol Cell. 2010; 40:294-309.

44. Wilson WR, Hay MP. Targeting hypoxia in cancer therapy. Nat Rev Cancer. 2011; 11:393-410.

45. Semenza GL. Hypoxia-inducible factors: mediators of cancer progression and targets for cancer therapy. Trends Pharmacol Sci. 2012; 33:207-214.
46. Rapisarda A, Melillo G. Overcoming disappointing results with antiangiogenic therapy by targeting hypoxia. Nat Rev Clin Oncol. 2012; 9:378-390.

47. Melillo G. Inhibiting hypoxia-inducible factor 1 for cancer therapy. Mol Cancer Res. 2006; 4:601-605.

48. Ader I, Malavaud B, Cuvillier O. When the sphingosine kinase-1/sphingosine 1-phosphate pathway meets hypoxia signaling: new targets for cancer therapy. Cancer Res. 2009; 69:3723-3726.

49. Cuvillier O, Ader I, Bouquerel P, Brizuela L, Gstalder C, Malavaud B. Hypoxia, therapeutic resistance, and sphingosine 1-phosphate. Adv Cancer Res. 2013; 117:117-141.

50. Ader I, Brizuela L, Bouquerel P, Malavaud B, Cuvillier O. Sphingosine kinase 1: a new modulator of hypoxia inducible factor 1alpha during hypoxia in human cancer cells. Cancer Res. 2008; 68:8635-8642.

51. Anelli V, Gault CR, Cheng AB, Obeid LM. Sphingosine Kinase 1 Is Up-regulated during Hypoxia in U87MG Glioma Cells: role of hypoxia-inducible factors 1 and 2 . J Biol Chem. 2008; 283:3365-3375.

52. Schnitzer SE, Weigert A, Zhou J, Brune B. Hypoxia enhances sphingosine kinase 2 activity and provokes sphingosine-1-phosphate-mediated chemoresistance in A549 lung cancer cells. Mol Cancer Res. 2009; 7:393-401.

53. Hisano Y, Kobayashi N, Yamaguchi A, Nishi T. Mouse SPNS2 functions as a sphingosine-1-phosphate transporter in vascular endothelial cells. PLoS One. 2012; 7:e38941.

54. Mendoza A, Breart B, Ramos-Perez WD, Pitt LA, Gobert M, Sunkara M, Lafaille JJ, Morris AJ, Schwab SR. The transporter spns2 is required for secretion of lymph but not plasma sphingosine-1-phosphate. Cell Rep. 2012; 2:1104-1110.

55. Blouw B, Song H, Tihan T, Bosze J, Ferrara N, Gerber HP, Johnson RS, Bergers G. The hypoxic response of tumors is dependent on their microenvironment. Cancer Cell. 2003; 4:133-146.

56. Pchejetski D, Golzio M, Bonhoure E, Calvet C, Doumerc N, Garcia V, Mazerolles C, Rischmann P, Teissie J, Malavaud B, Cuvillier O. Sphingosine kinase-1 as a chemotherapy sensor in prostate adenocarcinoma cell and mouse models. Cancer Res. 2005; 65:11667-11675.

57. Goertz DE, Yu JL, Kerbel RS, Burns PN, Foster FS. High-frequency Doppler ultrasound monitors the effects of antivascular therapy on tumor blood flow. Cancer Res. 2002; 62:6371-6375.

58. Wong CS, Sceneay J, House CM, Halse HM, Liu MC, George J, Hunnam TC, Parker BS, Haviv I, Ronai Z, Cullinane C, Bowtell DD, Moller A. Vascular normalization by loss of Siah2 results in increased chemotherapeutic efficacy. Cancer Res. 2012; 72:1694-1704.

59. Olivera A, Spiegel S. Sphingosine-1-phosphate as second messenger in cell proliferation induced by PDGF and FCS mitogens. Nature. 1993; 365:557-560. 
60. Cuvillier O, Rosenthal DS, Smulson ME, Spiegel S. Sphingosine 1-phosphate inhibits activation of caspases that cleave poly(ADP-ribose) polymerase and lamins during Fas- and ceramide-mediated apoptosis in Jurkat T lymphocytes. J Biol Chem. 1998; 273:2910-2916.

61. Petrylak DP, Tangen CM, Hussain MH, Lara PN Jr., Jones JA, Taplin ME, Burch PA, Berry D, Moinpour C, Kohli M, Benson MC, Small EJ, Raghavan D, et al. Docetaxel and estramustine compared with mitoxantrone and prednisone for advanced refractory prostate cancer. N Engl J Med. 2004; 351:1513-1520.

62. Tannock IF, de Wit R, Berry WR, Horti J, Pluzanska A, Chi KN, Oudard S, Theodore C, James ND, Turesson I, Rosenthal MA, Eisenberger MA. Docetaxel plus prednisone or mitoxantrone plus prednisone for advanced prostate cancer. N Engl J Med. 2004; 351:1502-1512.

63. Sensken SC, Nagarajan M, Bode C, Graler MH. Local inactivation of sphingosine 1-phosphate in lymph nodes induces lymphopenia. J Immunol. 2011; 186:3432-3440.

64. Jain RK. Molecular regulation of vessel maturation. Nat Med. 2003; 9:685-693.

65. Dejana E, Tournier-Lasserve E, Weinstein BM. The control of vascular integrity by endothelial cell junctions: molecular basis and pathological implications. Dev Cell. 2009; 16:209-221.

66. Gavard J, Gutkind JS. VEGF controls endothelial-cell permeability by promoting the beta-arrestin-dependent endocytosis of VE-cadherin. Nature cell biology. 2006; 8:1223-1234.

67. Morikawa S, Baluk P, Kaidoh T, Haskell A, Jain RK, McDonald DM. Abnormalities in pericytes on blood vessels and endothelial sprouts in tumors. Am J Pathol. 2002; 160:985-1000.

68. Raza A, Franklin MJ, Dudek AZ. Pericytes and vessel maturation during tumor angiogenesis and metastasis. American journal of hematology. 2010; 85:593-598.

69. Chen RR, Silva EA, Yuen WW, Mooney DJ. Spatiotemporal VEGF, and PDGF delivery patterns blood vessel formation and maturation. Pharm Res. 2007; 24:258-264.

70. Greenberg JI, Shields DJ, Barillas SG, Acevedo LM, Murphy E, Huang J, Scheppke L, Stockmann C, Johnson RS, Angle N, Cheresh DA. A role for VEGF as a negative regulator of pericyte function and vessel maturation. Nature. 2008; 456:809-813.

71. Xian $\mathrm{X}$, Hakansson $\mathrm{J}$, Stahlberg A, Lindblom $\mathrm{P}$, Betsholtz C, Gerhardt H, Semb H. Pericytes limit tumor cell metastasis. J Clin Invest. 2006; 116:642-651.

72. Cooke VG, LeBleu VS, Keskin D, Khan Z, O'Connell JT, Teng Y, Duncan MB, Xie L, Maeda G, Vong S, Sugimoto H, Rocha RM, Damascena A, et al. Pericyte depletion results in hypoxia-associated epithelial-to-mesenchymal transition and metastasis mediated by met signaling pathway. Cancer Cell. 2012; 21:66-81.
73. Yuan F, Chen Y, Dellian M, Safabakhsh N, Ferrara N, Jain RK. Time-dependent vascular regression and permeability changes in established human tumor xenografts induced by an anti-vascular endothelial growth factor/ vascular permeability factor antibody. Proc Natl Acad Sci U S A. 1996; 93:14765-14770.

74. Jain RK. Normalizing tumor vasculature with antiangiogenic therapy: a new paradigm for combination therapy. Nat Med. 2001; 7:987-989.

75. Winkler F, Kozin SV, Tong RT, Chae SS, Booth MF, Garkavtsev I, Xu L, Hicklin DJ, Fukumura D, di Tomaso E, Munn LL, Jain RK. Kinetics of vascular normalization by VEGFR2 blockade governs brain tumor response to radiation: role of oxygenation, angiopoietin- 1 , and matrix metalloproteinases. Cancer Cell. 2004; 6:553-563.

76. Dings RP, Loren M, Heun H, McNiel E, Griffioen AW, Mayo KH, Griffin RJ. Scheduling of radiation with angiogenesis inhibitors anginex and Avastin improves therapeutic outcome via vessel normalization. Clin Cancer Res. 2007; 13:3395-3402.

77. Matsumoto S, Batra S, Saito K, Yasui H, Choudhuri R, Gadisetti C, Subramanian S, Devasahayam N, Munasinghe JP, Mitchell JB, Krishna MC. Antiangiogenic agent sunitinib transiently increases tumor oxygenation and suppresses cycling hypoxia. Cancer Res. 2011; 71:6350-6359.

78. Willett CG, Boucher Y, di Tomaso E, Duda DG, Munn LL, Tong RT, Chung DC, Sahani DV, Kalva SP, Kozin SV, Mino M, Cohen KS, Scadden DT, et al. Direct evidence that the VEGF-specific antibody bevacizumab has antivascular effects in human rectal cancer. Nat Med. 2004; 10:145-147.

79. Batchelor TT, Sorensen AG, di Tomaso E, Zhang WT, Duda DG, Cohen KS, Kozak KR, Cahill DP, Chen PJ, Zhu M, Ancukiewicz M, Mrugala MM, Plotkin S, et al. AZD2171, a pan-VEGF receptor tyrosine kinase inhibitor, normalizes tumor vasculature and alleviates edema in glioblastoma patients. Cancer Cell. 2007; 11:83-95.

80. Willett CG, Duda DG, di Tomaso E, Boucher Y, Ancukiewicz M, Sahani DV, Lahdenranta J, Chung DC, Fischman AJ, Lauwers GY, Shellito P, Czito BG, Wong TZ, et al. Efficacy, safety, and biomarkers of neoadjuvant bevacizumab, radiation therapy, and fluorouracil in rectal cancer: a multidisciplinary phase II study. J Clin Oncol. 2009; 27:3020-3026.

81. Emblem KE, Mouridsen K, Bjornerud A, Farrar CT, Jennings D, Borra RJ, Wen PY, Ivy P, Batchelor TT, Rosen BR, Jain RK, Sorensen AG. Vessel architectural imaging identifies cancer patient responders to antiangiogenic therapy. Nat Med. 2013; 19:1178-1183.

82. Sorensen AG, Batchelor TT, Zhang WT, Chen PJ, Yeo P, Wang M, Jennings D, Wen PY, Lahdenranta J, Ancukiewicz M, di Tomaso E, Duda DG, Jain RK. A "vascular normalization index" as potential mechanistic biomarker to predict survival after a single dose of cediranib in recurrent glioblastoma patients. Cancer Res. 2009; 69:5296-5300. 
83. Batchelor TT, Duda DG, di Tomaso E, Ancukiewicz M, Plotkin SR, Gerstner E, Eichler AF, Drappatz J, Hochberg FH, Benner T, Louis DN, Cohen KS, Chea H, et al. Phase II study of cediranib, an oral pan-vascular endothelial growth factor receptor tyrosine kinase inhibitor, in patients with recurrent glioblastoma. J Clin Oncol. 2010; 28:2817-2823.

84. Sorensen AG, Emblem KE, Polaskova P, Jennings D, Kim H, Ancukiewicz M, Wang M, Wen PY, Ivy P, Batchelor TT, Jain RK. Increased survival of glioblastoma patients who respond to antiangiogenic therapy with elevated blood perfusion. Cancer Res. 2012; 72:402-407.

85. Cho SY, Lee HJ, Jeong SJ, Kim HS, Chen CY, Lee EO, $\mathrm{Kim} \mathrm{SH}$. Sphingosine kinase 1 pathway is involved in melatonin-induced HIF-1alpha inactivation in hypoxic PC-3 prostate cancer cells. J Pineal Res. 2011; 51:87-93.

86. Kalhori V, Kemppainen K, Asghar MY, Bergelin N, Jaakkola P, Tornquist K. Sphingosine-1-Phosphate as a Regulator of Hypoxia-Induced Factor-1alpha in Thyroid Follicular Carcinoma Cells. PLoS One. 2013; 8:e66189.

87. Garcia JG, Liu F, Verin AD, Birukova A, Dechert MA, Gerthoffer WT, Bamberg JR, English D. Sphingosine 1-phosphate promotes endothelial cell barrier integrity by Edg-dependent cytoskeletal rearrangement. J Clin Invest. 2001; 108:689-701.

88. Gaengel K, Niaudet C, Hagikura K, Lavina B, Muhl L, Hofmann JJ, Ebarasi L, Nystrom S, Rymo S, Chen LL, Pang MF, Jin Y, Raschperger E, et al. The sphingosine1-phosphate receptor S1PR1 restricts sprouting angiogenesis by regulating the interplay between VE-cadherin and VEGFR2. Dev Cell. 2012; 23:587-599.

89. Jung B, Obinata H, Galvani S, Mendelson K, Ding BS, Skoura A, Kinzel B, Brinkmann V, Rafii S, Evans T, Hla T. Flow-regulated endothelial S1P receptor-1 signaling sustains vascular development. Dev Cell. 2012; 23:600-610.

90. Liu Y, Wada R, Yamashita T, Mi Y, Deng CX, Hobson JP, Rosenfeldt HM, Nava VE, Chae SS, Lee MJ, Liu CH, Hla T, Spiegel S, et al. Edg-1, the G protein-coupled receptor for sphingosine-1-phosphate, is essential for vascular maturation. J Clin Invest. 2000; 106:951-961.

91. Allende ML, Yamashita T, Proia RL. G-protein-coupled receptor S1P1 acts within endothelial cells to regulate vascular maturation. Blood. 2003; 102:3665-3667.

92. Paik JH, Skoura A, Chae SS, Cowan AE, Han DK, Proia RL, Hla T. Sphingosine 1-phosphate receptor regulation of N-cadherin mediates vascular stabilization. Genes Dev. 2004; 18:2392-2403.

93. Sanchez T, Skoura A, Wu MT, Casserly B, Harrington EO, Hla T. Induction of vascular permeability by the sphingosine-1-phosphate receptor-2 (S1P2R) and its downstream effectors ROCK and PTEN. Arterioscler Thromb Vasc Biol. 2007; 27:1312-1318.

94. Zhang G, Yang L, Kim GS, Ryan K, Lu S, O’Donnell RK, Spokes K, Shapiro N, Aird WC, Kluk MJ, Yano K, Sanchez T. Critical role of sphingosine-1-phosphate receptor 2 (S1PR2) in acute vascular inflammation. Blood. 2013; 122:443-455.
95. Skoura A, Sanchez T, Claffey K, Mandala SM, Proia RL, Hla T. Essential role of sphingosine 1-phosphate receptor 2 in pathological angiogenesis of the mouse retina. J Clin Invest. 2007; 117:2506-2516.

96. Michaud MD, Robitaille GA, Gratton JP, Richard DE. Sphingosine-1-phosphate: a novel nonhypoxic activator of hypoxia-inducible factor-1 in vascular cells. Arterioscler Thromb Vasc Biol. 2009; 29:902-908.

97. Du W, Takuwa N, Yoshioka K, Okamoto Y, Gonda K, Sugihara K, Fukamizu A, Asano M, Takuwa Y. S1P(2), the $\mathrm{G}$ protein-coupled receptor for sphingosine-1-phosphate, negatively regulates tumor angiogenesis and tumor growth in vivo in mice. Cancer Res. 2010; 70:772-781.

98. Lawrence YR, Dicker AP. Hypoxia in prostate cancer: observation to intervention. The lancet oncology. 2008; 9:308-309.

99. Weidner N, Carroll PR, Flax J, Blumenfeld W, Folkman J. Tumor angiogenesis correlates with metastasis in invasive prostate carcinoma. Am J Pathol. 1993; 143:401-409.

100. Russo G, Mischi M, Scheepens W, De la Rosette JJ, Wijkstra H. Angiogenesis in prostate cancer: onset, progression and imaging. BJU Int. 2012; 110:E794-808.

101. Mucci LA, Powolny A, Giovannucci E, Liao Z, Kenfield SA, Shen R, Stampfer MJ, Clinton SK. Prospective study of prostate tumor angiogenesis and cancer-specific mortality in the health professionals follow-up study. J Clin Oncol. 2009; 27:5627-5633.

102. George DJ, Halabi S, Shepard TF, Vogelzang NJ, Hayes DF, Small EJ, Kantoff PW, Cancer Leukemia Group. Prognostic significance of plasma vascular endothelial growth factor levels in patients with hormone-refractory prostate cancer treated on Cancer and Leukemia Group B 9480. Clin Cancer Res. 2001; 7:1932-1936.

103. Kelly WK, Halabi S, Carducci M, George D, Mahoney JF, Stadler WM, Morris M, Kantoff P, Monk JP, Kaplan E, Vogelzang NJ, Small EJ. Randomized, double-blind, placebo-controlled phase III trial comparing docetaxel and prednisone with or without bevacizumab in men with metastatic castration-resistant prostate cancer: CALGB 90401. J Clin Oncol. 2012; 30:1534-1540.

104. Tannock IF, Fizazi K, Ivanov S, Karlsson CT, Flechon A, Skoneczna I, Orlandi F, Gravis G, Matveev V, Bavbek S, Gil T, Viana L, Aren O, et al. Aflibercept versus placebo in combination with docetaxel and prednisone for treatment of men with metastatic castration-resistant prostate cancer (VENICE): a phase 3, double-blind randomised trial. The lancet oncology. 2013; 14:760-768.

105. Galsky MD, Oh WK. Tumour angiogenesis: an elusive target in castration-resistant prostate cancer. The lancet oncology. 2013; 14:681-682.

106. Milosevic M, Chung P, Parker C, Bristow R, Toi A, Panzarella T, Warde P, Catton C, Menard C, Bayley A, Gospodarowicz M, Hill R. Androgen withdrawal in patients reduces prostate cancer hypoxia: implications for disease progression and radiation response. Cancer Res. 2007; 67:6022-6025. 
107. Milosevic M, Warde P, Menard C, Chung P, Toi A, Ishkanian A, McLean M, Pintilie M, Sykes J, Gospodarowicz M, Catton C, Hill RP, Bristow R. Tumor Hypoxia Predicts Biochemical Failure following Radiotherapy for Clinically Localized Prostate Cancer. Clin Cancer Res. 2012; 18:2108-2114.

108. Benjamin LE, Golijanin D, Itin A, Pode D, Keshet E. Selective ablation of immature blood vessels in established human tumors follows vascular endothelial growth factor withdrawal. J Clin Invest. 1999; 103:159-165.

109. Roe K, Mikalsen LT, van der Kogel AJ, Bussink J, Lyng H, Ree AH, Marignol L, Olsen DR. Vascular responses to radiotherapy and androgen-deprivation therapy in experimental prostate cancer. Radiat Oncol. 2012; 7:75.
110. Widmark A, Klepp O, Solberg A, Damber JE, Angelsen A, Fransson P, Lund JA, Tasdemir I, Hoyer M, Wiklund F, Fossa SD Scandinavian Prostate Cancer Group S, Swedish Association for Urological O. Endocrine treatment, with or without radiotherapy, in locally advanced prostate cancer (SPCG-7/SFUO-3): an open randomised phase III trial. Lancet. 2009; 373:301-308.

111. Denham JW, Steigler A, Lamb DS, Joseph D, Turner S, Matthews J, Atkinson C, North J, Christie D, Spry NA, Tai KH, Wynne C, D'Este C. Short-term neoadjuvant androgen deprivation and radiotherapy for locally advanced prostate cancer: 10 -year data from the TROG 96.01 randomised trial. The lancet oncology. 2011; 12:451-459. 